NBER WORKING PAPER SERIES

\title{
DO COLLEGE APPLICANTS RESPOND TO CHANGES IN STICKER PRICES EVEN WHEN THEY DON'T MATTER?
}

\author{
Phillip B. Levine \\ Jennifer Ma \\ Lauren C. Russell \\ Working Paper 26910 \\ http://www.nber.org/papers/w26910 \\ NATIONAL BUREAU OF ECONOMIC RESEARCH \\ 1050 Massachusetts Avenue \\ Cambridge, MA 02138 \\ March 2020
}

We are grateful to seminar participants at the National Bureau of Economic Research Fall Education Program Meeting, Dartmouth College, Harvard University Graduate School of Education, Lafayette College, Swarthmore College, Wellesley College, and the DC Economics of Education seminar for their comments and suggestions. This manuscript uses proprietary data from the College Board, which has reviewed this manuscript and granted permission to release it. The views and opinions expressed in this paper are those of the authors alone. Phillip Levine is also the founder and CEO of MyinTuition Corp., a non-profit organization that provides participating colleges and universities with simplified financial aid calculators. The views expressed herein are those of the authors and do not necessarily reflect the views of the National Bureau of Economic Research.

NBER working papers are circulated for discussion and comment purposes. They have not been peer-reviewed or been subject to the review by the NBER Board of Directors that accompanies official NBER publications.

(C) 2020 by Phillip B. Levine, Jennifer Ma, and Lauren C. Russell. All rights reserved. Short sections of text, not to exceed two paragraphs, may be quoted without explicit permission provided that full credit, including $\odot$ notice, is given to the source. 
Do College Applicants Respond to Changes in Sticker Prices Even When They Don't Matter?

Phillip B. Levine, Jennifer Ma, and Lauren C. Russell

NBER Working Paper No. 26910

March 2020

JEL No. I22,J24

\begin{abstract}
$\underline{\text { ABSTRACT }}$ colleges because of the perceived high cost. We test for this form of "sticker shock" using College Board data on SAT scores sends, as a proxy for applications, to state flagship institutions for students entering college in 2006-2013. Some public flagships guarantee financial aid will crisis generated from state budget shortfalls. We also control for local labor market conditions to abstract from the recession's impact on individual educational decisions. We find evidence of flagships reduce enrollment of high achieving students, regardless of financial aid status, who often choose private colleges instead.

\author{
Phillip B. Levine \\ Department of Economics \\ Wellesley College \\ 106 Central Street \\ Wellesley, MA 02481 \\ and NBER \\ plevine@wellesley.edu \\ Jennifer Ma \\ College Board \\ 1919 M Street NW \\ Washington, DC 20036 \\ jma@collegeboard.org
}

\author{
Lauren C. Russell \\ University of Pennsylvania \\ 3814 Walnut Street \\ Philadelphia, PA 19104 \\ 1rus@sas.upenn.edu
}

Fels Institute of Government
\end{abstract}

Do students respond to sticker prices or actual prices when applying to college? These costs differ for students eligible for financial aid. Students who do not understand this may not apply to some meet full financial need. Sticker price increases at those schools would not affect the actual cost after factoring in financial aid and should not affect decisions for those eligible for aid. We exploit the large and variable increases in sticker prices at public flagships during the financial sticker shock - students unaffected by virtue of institutional aid policies still apply less often. Using data from the National Student Clearinghouse, we also find that price increases at public 


\section{Introduction}

Students from low- and moderate-income families are substantially under-represented at public flagship universities. Only 27 percent of students at those institutions come from the bottom 60 percent of the parental income distribution. ${ }^{1}$ Those whose parents are in the top 40 percent of the income distribution represent 73 percent of students. A student at a public flagship is nine times more likely to come from the top 20 percent of the parental income distribution than the bottom 20 percent.

These patterns are troubling given that public flagships have the potential to be engines of upward mobility (Chetty et al., 2020). Notably, the underrepresentation of children from lowand moderate-income families has been increasing over time. Three-fourths of public flagships enroll a lower percentage of these students today than they did in the late 1990 s. $^{2}$

A lack of understanding of college pricing and the financial aid system may contribute to this pattern. Prior work, which has focused almost exclusively on low-income, high-achieving students, documents that it is at the college application stage — rather than at the point of admissions or matriculation - where the behavior of low-income students differs most from their higher-income peers (Hoxby and Avery, 2013; Hoxby and Turner, 2015). Perceived costs are one of the most important factors influencing where students apply. Sixty-seven percent of families report factoring in the price of college when finalizing college application lists, and a majority of high school seniors report ruling out colleges based on sticker prices alone, without considering their likely financial aid awards (Sallie Mae, 2016; The College Board and Arts \& Sciences Group, 2012). In another survey, 44 percent of students destined for public colleges and universities reported rejecting colleges at the application stage based on published sticker prices alone (Longmire \& Company, 2013).

\footnotetext{
${ }^{1}$ Authors' analysis of data from Chetty et al. (2017). These statistics are based on those flagship institutions that can be separately identified in the Mobility Report Cards and reflect the most recent data year available (children born in 1991).

${ }^{2}$ Authors' analysis of data from Chetty et al. (2017).
} 
"Sticker shock" occurs when students are discouraged from applying to schools based on the sticker price, ignoring the potential availability of financial aid. Although sticker prices for in-state students at public flagship institutions are considerably lower than those at highly selective private colleges, they are still generally higher than alternative public options, like community colleges or regional, less-selective public four-year colleges. Inadequate knowledge of financial aid and the true cost of attending a public flagship institution may contribute to the observed enrollment patterns of low- and moderate-income students.

The 2008-09 financial crisis provides us with an opportunity to examine the existence and extent of sticker shock. Many states dramatically increased tuition and fees at public postsecondary institutions at that time due to dramatic declines in state appropriations (Long, 2015). Since these tuition increases were heavily covered by the news media, it is likely that they were well known by students of college-going age or their parents, and some students may not have applied to their public flagship as a result. ${ }^{3}$

In some states, though, financial aid policies were in place that would have protected aideligible students from experiencing increases in costs of attendance. A handful of public flagships have a policy of "meeting full demonstrated financial need" (at least for state residents). That is, they provide enough financial aid through grants, work study, and loans to fill the gap between the sticker price and the "Expected Family Contribution (EFC)", which is the amount a student and her family can "afford" as determined by the financial aid system. For aideligible students at an institution that meets full financial need, an increase in the sticker cost of attendance (COA) would not increase their EFCs, which are determined only by their finances. ${ }^{4}$

\footnotetext{
${ }^{3}$ For example, see Duke (2009), Asimov (2009), and Gordon and Khan (2009). Because the news media focused primarily on increases in tuition and fees rather than costs of attendance, we use tuition and fees as our primary price measure. We also explore the sensitivity of our results to the use of cost of attendance.

${ }^{4}$ Most public flagships use the Federal Methodology (FM) to determine a family's Expected Family Contribution. This methodology uses information reported on the Free Application for Federal Student including family size, the number of children enrolled in higher education, the age of the older parent, and the income and assets of the parent and student. Unlike the Institutional Methodology (IM), used by a few public flagships and hundreds of private institutions, the FM does not consider the net value of a family's primary residence or small businesses owned by the family.
} 
This institutional framework sets up a quasi-experiment that we use to examine the impact of the sticker price on college-going behavior. In this paper, we focus on students' decisions to apply to public flagship universities, taking advantage of changes in tuition sticker prices and the fact that low- and moderate-income students in states that meet full need were not subject to price increases. We instrument sticker prices using the "state budget shocks" approach used by Deming and Walters (2017) to further focus our analysis on the impact of recessionrelated budget cuts. We also control for the local labor market conditions, which could directly impact students’ resources and college-going.

When the financial crisis hit, it made college more expensive for financial aid recipients at public flagships that do not meet full need, but not at those that do meet full need. If we observe a reduction in applications among students likely to receive financial aid in state flagships that meet full need in the years immediately following the financial crisis, this would support the notion that sticker shock exists.

Our results indicate that sticker shock is indeed an issue that affects application decisions of potential college students who would be eligible for financial aid. Overall, students are sensitive to changes in sticker prices in the application stage of the process. A 10 percent increase in sticker prices at a public flagship generates around a 1.2 to 1.8 percentage point reduction in the likelihood of applying to an institution, as proxied by sending SAT scores to that institution. Importantly, we find little difference in that impact between students likely to be eligible for financial aid at schools that meet full need compared to those that do not. Since aideligible students should not respond to changes in sticker prices at meet-full-need schools, we interpret these results as evidence of sticker shock.

We also find that price increases at public flagships have little impact on total enrollments among all students, regardless of their financial aid/meet-full-need status. Public flagships maintain their enrollment by lowering their admissions standards, enrolling fewer high 
achieving students. We see a commensurate increase in enrollments among those high achievers at private not-for-profit four-year colleges instead.

\section{Institutional Details and Trends in College Pricing}

\subsection{Past Research}

Some prior work has investigated whether making net prices more salient affects collegegoing. The net price represents the sum of all resources that a family needs to pay, including cash, loans, and work-study funds, to cover the cost of attendance. It is equivalently calculated as the COA less the direct grant aid offered to the student from any source (federal, state, institutional, or other).

The evidence on whether students respond to net prices is mixed. Providing students with the average price of attendance after factoring in financial aid does not have a large impact on college-going intentions (Bleemer and Zafar, 2018). Similarly, making average net price information more easily available through the College Scorecard has had no effect on college application as proxied by SAT score sending or online college search behavior (Hurwitz and Smith, 2018; Huntington-Klein, 2016).

Levine (2014) argues that what students want are estimates that are specific to them, not on average. This is consistent with the findings of Bettinger et al. (2012), which shows that providing individualized cost information along with assistance completing financial aid forms had a large impact on college attendance. Similarly, Hoxby and Turner (2013) find that providing semi-customized information on college net costs along with other information regarding academic "fit" causes high-achieving, low-income students to apply and be admitted to more colleges. ${ }^{5}$ Dynarski et al. (2018) find that a marketing campaign touting free tuition for those with incomes under $\$ 60,000$, which was not a change from previous pricing policy, had a large impact on applications and enrollments.

\footnotetext{
${ }^{5}$ It is important to note that Gurantz, et al. (2019) report that they did not find significant enrollment effect from a series of large randomized control trials that focused on reducing information barrier for low- and middle-income high-achieving or on-track students.
} 
The studies that are closest to our work is Hemelt and Marcotte (2011) and Deming and Walters (2017), both of which examine the impact of tuition changes at public institutions on enrollment. Hemelt and Marcotte use data from 1991 through 2006 and use OLS to estimate their models. Deming and Walters recognize the potential endogeneity problem in determining levels of tuition and estimate their models using state budget shares as an instrument, which we describe in more detail below. They use data from 1990 through 2013 in their analysis. They also examine the impact of a school's expenditures on enrollment, an issue we also return to below. Neither of these papers, though, focuses on sticker shock; they do not distinguish students by income or institutions by meet-full-need status, which is the focus of our analysis.

\subsection{Financial Aid Policy and the Impact of Price Increases}

The interaction between a meet-full-need financial aid policy and price increases is critical to our empirical strategy; we describe that here. A critical component of a financial aid system is a determination of what the family can afford to pay. Ignoring the obvious difficulty in setting that amount, this is the purpose of completing the FAFSA. ${ }^{6}$ The "expected family contribution (EFC)” is the calculated ability to pay, which is constructed based on a family's financial attributes as reported on the FAFSA.

At meet-full-need institutions, students with an EFC below COA receive enough financial aid (through grants, loans, or work-study) so that the net price they pay combined with their financial aid equals the COA. ${ }^{7}$ This is not true at institutions that do not meet full need. Students who are eligible for financial aid at those institutions are required to pay more than their EFC.

When COA rises, families with sufficient financial resources to afford the COA at the original and new levels pay full price either way. They face the entire price increase. The impact

\footnotetext{
${ }^{6}$ Using FAFSA alone to determine ability to pay is called the "federal methodology (FM)." Many schools also rely on the CSS Profile and "institutional methodology (IM)." All state flagships that do not meet full need use FM.

${ }^{7}$ There is a distinction between schools that meet full need and those that are "need-blind" in admission, meaning that acceptance decisions are independent of financial need. All schools that are need-blind also meet full need, but not vice versa. In our analysis, all state flagships that meet full need are at least need-blind for students residing in that state, which is the group our analysis focuses on.
} 
of the price increase on financial aid recipients depends on the school's meet-full-need status. At a school that meets full need, financial aid adjusts to fill in the new, larger gap between COA and the student's EFC. An increase in the COA has no bearing on their net price. ${ }^{8}$ If the school does not meet full need, then the student will be expected to pay more as tuition increases.

This institutional detail sets up the natural experiment we exploit in our empirical analysis. At institutions that do not meet full need, an increase in the sticker price affects all students. At institutions that meet full need, an increase in the sticker price only affects those students who can afford to pay that higher price. ${ }^{9}$ Therefore, the spike in sticker prices following the financial crisis should not have affected low- and moderate-income students at meet-fullneed schools. It would have affected higher-income students at those schools and all students at schools that do not meet full need.

\subsection{Financial Aid Policy in Practice}

To demonstrate the variability in financial aid systems across state flagship institutions, we calculated net prices using each school's net price calculator for a dependent student with household income of $\$ 50,000$ and no assets. ${ }^{10}$ According to the FAFSA4caster, an online tool that estimates eligibility for federal financial aid, this family is estimated to have an EFC of \$2,600 (with rounding) in 2019. ${ }^{11}$ Loans and work-study would be expected in addition to the EFC. First-year undergraduate students can borrow up to $\$ 5,500$ through the federal student loan system (including subsidized and unsubsidized loans), and it is not uncommon for schools to

\footnotetext{
${ }^{8}$ This discussion overlooks the group of students who are just on the cusp of financial aid eligibility before the COA increase in a meet-full-need state. That COA increase will qualify those students for aid, protecting them from some portion of the higher cost. In practice, the part of the income distribution where students are on that financial aid margin is thin enough that the number of students affected in this way is small. We do not address that issue in our analysis.

${ }^{9}$ In theory, colleges could continue to meet full need and increase their revenue by increasing expected loan burdens, which are also incorporated into a complete financial aid award. In practice, most colleges and universities set their loan expectations at the maximum allowed by federal Stafford Loans $(\$ 3,500$ subsidized or $\$ 5,500$ including an additional $\$ 2,000$ of unsubsidized loans).

${ }^{10}$ We also assumed the student was 18 years old, unmarried, with no dependents, was applying to college for the first time, and had one younger sibling. We further assumed that the student's parents were 47 and 48 years old, married, and paid no income tax. Appendix Table A.1 provides a list of these flagship institutions. The state flagship institutions in California and Texas are Berkeley and Austin, respectively.

${ }^{11}$ The exact EFC depends on the state and ranges from $\$ 2,111$ to $\$ 3,036$. We use $\$ 2,600$ as an average for illustrative purposes in this discussion.
} 
offer students up to \$3,500 in work-study funds. Accordingly, an institution that charged this student \$11,600 after grant aid would be meeting her full need. If a school charged this student more than $\$ 11,600$ after grant aid, the school would not have met full need. The gap is labeled "unmet need."

Because of variation in whether a flagship meets full financial need, students at schools with very similar full costs of attendance can face vastly different financial burdens after factoring in financial aid. Figure 1 documents the amount of unmet financial need across states for a hypothetical dependent student living on-campus with household income of $\$ 50,000$, no assets, two married parents, and one other sibling who is not in college. All calculations are based on information provided by net price calculators posted on university websites in fall 2019. In some states (California, Michigan, North Carolina, Virginia, Delaware, Illinois, Washington, Wisconsin, and Wyoming), a student with that financial profile would have his/her entire financial need met. All of these states, other than Wyoming, have policies dictating that they meet full need, at least for those with modest incomes. ${ }^{12}$ This student would have unmet financial need in the remainder of the states, facing a price higher than she could "afford." The amount of this unmet need ranges from \$2,000 in Florida to \$16,000 in Alabama. ${ }^{13}$

For the sample period we use in our empirical analysis, we categorize the flagship institutions in California (Berkeley), Michigan (UM), North Carolina (UNC), and Virginia (UVA) as meeting full need, at least for residents of each state. Illinois and Wisconsin adopted

\footnotetext{
${ }^{12}$ The follobwing webpages identify each state's policy of meeting full demonstrated financial need: https://finaid.umich.edu/how-aid-is-awarded/ (University of Michigan - Ann Arbor), https://sfs.virginia.edu/need (University of Virginia), http://admission.universityofcalifornia.edu/paying-for-uc/how-aid-works/index.html (University of California System), https://admissions.unc.edu/files/2013/09/Financial-Aid-Fact-Sheet.pdf (University of North Carolina - Chapel Hill), https://www.udel.edu/apply/undergraduate-admissions/financingyour-degree/ (University of Delaware; effective fall 2009), and https://www.washington.edu/huskypromise/ (University of Washington). The University of Wisconsin - Madison began the Bucky's Tuition Promise program which guarantees free tuition and no fees for incoming freshman for families earning less than $\$ 56,000$ per year in the 2018-2019 school year (https://financialaid.wisc.edu/uw-madison-free-tuition-for-families-making-less-than56k/). The University of Illinois began the Illinois Commitment program which provides free tuition for families earning less than $\$ 61,000$ per year in the 2019-2020 school year (https://osfa.illinois.edu/illinois-commitment/).

${ }^{13}$ These amounts are for a student at the $25^{\text {th }}$ percentile of the school's GPA and SAT distribution who would likely not qualify for merit aid.
} 
their policies after our sample period ended (and only do so now for students with lower

incomes). Delaware and Washington implemented their policies partway through our 2006-2013

sample period, requiring us to drop them from our analysis altogether. ${ }^{14}$

Changes in cost of attendance, which are largely driven by changes in tuition and fees

(and, typically, smaller changes in room and board), have very different impacts on actual net prices depending on whether the school meets full financial need or not. If a meet-full-need institution raises its tuition and fees by $\$ 1,000$, the price paid by the student with household income of $\$ 50,000$ will not change. Her net price is determined solely by the self-help expectation and EFC, and her grant aid would increase by exactly $\$ 1,000$ to offset the price increase. The same student, however, at a school that does not meet full need would see her net price increase by the full amount of the tuition increase.

This is the intuition that underlies our empirical strategy. Aid-eligible students in states where the flagship meets full financial need should not respond to sticker price increases since their actual price paid does not change with the increase. ${ }^{15}$ Aid-ineligible students and aideligible students in states where the public flagship does not meet full financial need may respond by decreasing application and enrollments.

\footnotetext{
${ }^{14}$ We also drop Pennsylvania and Wyoming from our analysis. In Pennsylvania, SAT score sends cannot be reliably matched to specific public institutions in PA. Wyoming does not have an official policy to meet full need. However, calculations from its net price calculator suggest that low-income students have no unmet need. How an increase in COA translates to a student's net price is unclear in such a system, so we have chosen to drop it from our analysis. This leaves us with 46 states used in our analysis (note: the District of Columbia has no flagship institution), 4 of which meet full need and 42 do not.

${ }^{15}$ In theory, "meet-full-need" schools could shift costs onto aid-eligible students in response to a budget shortfall by increasing loan expectations and reducing grant aid. In practice, however, we see little evidence that the schools we identify as meeting full need did that. Loan burdens increased at many institutions in 2007-08, in response to a federal increase in the maximum Stafford Loan. That would be captured by year fixed effects, though. Identifying school-specific changes in these policies during the financial crisis is difficult given the proprietary nature of this information. We are able to document, though, that overall borrowing at the UC Berkeley and the University of Michigan did not change noticeably in 2009-10. We are also able to document that the University of Virginia and the University of North Carolina had policies in place through this period that eliminate loans from the financial aid package for lower-income students. Based on this evidence, we conclude that shifting costs onto aid-eligible students through increasing loan expectations did not occur in a meaningful way at the schools we label as meet full need in response to the recession.
} 


\subsection{Trends in College Pricing}

Despite the importance of the full cost of attendance in determining the actual cost to students after factoring in financial aid as illustrated above, in the remainder of this analysis we focus on tuition (and fees) to capture "sticker price.” The difference between the two measures reflects room and board (most incoming students at public flagship institutions live on campus), along with an estimate of the cost of books, travel, and other miscellaneous expenses. We focus on tuition because changes in tuition prices reflect what the media typically reports (cf. Duke, 2009; Asimov, 2009, and Gordon and Khan, 2009). We explore the sensitivity of our results to this decision subsequently, but that is what students are likely to know and to respond to.

Another advantage of using tuition rather than cost of attendance is that the former is the price that is often set by the state government or the state board of higher education. ${ }^{16}$ Expenses beyond tuition and fees generally are not set at the state level and are largely designed to cover costs. Our instrumental variable strategy is based on the relationship between state economic conditions, budget issues, and the need for revenue from state colleges and universities. Tuition is the component of college costs that captures this.

The Great Recession that started in 2008 led to a large jump in sticker tuition at public flagship universities. Figure 2 uses data from the Integrated Postsecondary Data System (IPEDS) to show yearly increases in real tuition and fees from 2006 to 2013 (measured in August 2013 dollars using the CPI-U for adjustment). ${ }^{17}$ At the height of the recession in 2009, public flagships increased their tuition and fees by 9 percent on average in real terms. In the following year, tuition jumped by another 6 percent in real terms. In nominal terms, the increases were even larger, prompting widespread media coverage and outcry over the increases. In California, for example, the California Board of Regents instituted a 32 percent (nominal) tuition hike because of the state's large budget deficit, and students protested at several campuses (Duke, 2009).

\footnotetext{
${ }^{16}$ See Zinth and Smith (2012) for a categorization of tuition-setting authority by state.

${ }^{17}$ The statistics reported here are calculated using one observation per school. We have also estimated analogous statistics weighted by the number of SAT score senders in each state. The patterns in the data are similar, but with an even larger spike in tuition and fees during the recession.
} 
Tuition increases were much larger in states that were more heavily affected by the recession. As shown in Figure 3, in states where the state unemployment rate increased by less than 5 percentage points, average real tuition increased by 7.7 percent in $2009-10 .{ }^{18}$ By contrast, in states where the state unemployment rate increased by more than 5 percentage points, tuition increased by 12.8 percent. Increases in each of the next two years were considerably larger in these states as well.

Low- and moderate-income students living in states where the public flagship meets full financial need were insulated from the increases in tuition and fees. Any increase in tuition would be met with additional grant aid for financial aid recipients, wiping out any revenue gain from those students. Any increase in revenue at those institutions would have been realized from students not receiving financial aid. As a result, larger tuition increases are required at meet-fullneed flagships to generate the same revenue as that raised from flagships that do not meet full need. Indeed, that is what we see in the data. Figure 4 shows that schools with a policy of meeting full financial need raised tuition and fees more during the financial crisis than those that did not meet full need. ${ }^{19}$

This finding sets up an interesting potential paradox. Schools with meet-full-need financial aid policies do so to benefit aid-eligible students. Yet when financial circumstances require them to increase tuition, they must increase tuition by larger amount since those increases are only paid by a subset of students. But if students respond to the sticker price and not their true cost, the aid-eligible students (and others) may respond by reducing their likelihood of applying. Whether there is empirical support for this response is the focus of the remainder of our analysis.

\footnotetext{
${ }^{18}$ Our econometric models rely on state appropriations to distinguish economic activity, but within-state change in this measure and the unemployment rate are very highly correlated. A regression of the state budget shock on the unemployment rate in a model including state fixed effects has an $\mathrm{R}^{2}$ of 0.97 . We use the change in the unemployment rate here for the purposes of ease of interpretation.

${ }^{19}$ We sought to investigate the hypothesis that marginal revenue generated from a tuition increase is lower at meetfull-need schools. Unfortunately, we were unable to locate data on revenue from tuition restricted to undergraduates.
} 


\section{Data Description and Preliminary Analysis}

\subsection{Data Description}

To investigate the application response to prices, we use data on SAT score sends from the College Board. ${ }^{20}$ These data cover all students in the 2006 through 2013 high school graduation cohorts who took the SAT and sent at least one score report to a college or university. Following prior work by Pallais (2015) and Hurwitz and Smith (2018), we use the sending of a test score report to proxy for applying to a particular college.

We also have information on each student's SAT scores, demographics (race, gender, and parental education) and zip code. Our primary strategy is to use each student's zip code to determine whether the student is "likely aid-eligible." We assume that the student is aid-eligible if the median family income in her zip code is $\$ 75,000$ or less based on our analysis of data from the 2013 five-year sample of the American Community Survey. Eighty-four percent of families in these zip codes have incomes less than $\$ 100,000$ and 95 percent have incomes less than $\$ 150,000$. At a public flagship institution with a cost of attendance around $\$ 30,000$, the income cut-off for aid eligibility for families with typical asset values is in the vicinity of $\$ 125,000$. Perhaps 90 percent of families we define to be likely aid-eligible are actually eligible for financial aid. We report below sensitivity analyses designed to test alternative proxies for financial aid-eligibility, including self-reported income.

Although we have data on the universe of SAT takers who sent at least one score, we do not have data corresponding to ACT score send reports. The SAT is the dominant test on the coasts, but not the Midwest, as shown in Appendix Figure A.1. It is unlikely that changes in student preferences for sending an SAT versus ACT score would be impacted by the tuition of the public flagship in their state, so we do not believe that our use of SAT score-sending alone is an issue for our empirical strategy. Nevertheless, in our regressions, we control for the percent of

\footnotetext{
${ }^{20}$ These data are derived from data provided by the College Board (Copyright $($ C 2006-2013 The College Board. www.collegeboard.org)
} 
high school graduates in the state taking the SAT. ${ }^{21}$ We also include year fixed effects to control for the secular decline in SAT score sending relative to ACT score sending over our study period. $^{22}$

Among the 26.7 million graduating high school seniors in the 2006 to 2013 cohorts, 11.6 million (43 percent) had taken the SAT and 8.5 million (74 percent of SAT takers) sent scores to at least one college. Around 2.6 million SAT takers had sent scores to state flagships during this period.

We examine enrollment behavior among applicants using merged College Board and National Student Clearinghouse (NSC) data. The NSC data cover about 98 percent of all undergraduate enrollment in the United States. It records up to four postsecondary institutions in which a student enrolls. For our analysis, we consider a student enrolled in a flagship if either of her first two postsecondary institutions within 180 days of high school graduation is a flagship. Using this definition, 9 percent of total SAT senders (or 23 percent of flagship SAT senders) in our analysis enrolled in a flagship.

Information on sticker prices comes from the Integrated Postsecondary Education Data System (IPEDS). As we described earlier, we use in-state tuition and fees as our primary sticker price measure and CPI-adjust all prices to 2013 dollars using the CPI-U index in our analysis. Our state budget shock instrument is constructed using data on total state appropriations per student per year and the share of each flagship institution's total revenue that comes from state appropriations in a base year. The institution-specific data comes from IPEDS, the state appropriations data comes from the State Higher Education Executive Officers Association

\footnotetext{
${ }^{21}$ This is defined as the percentage of high school graduates in the cohort who take the SAT and submit at least one score report.

${ }^{22}$ See Adams (2017) for a discussion of how the popularity of the SAT and ACT has changed over time.
} 
(2018), and the number of high school students in the state comes from the Western Interstate Commission for Higher Education (2016).

Preliminary Analysis

Before providing a more technical assessment of sticker prices on score sending and enrollments, we start with a descriptive analysis of the raw data. Figures 3 and 4, reported earlier, document the differential price changes by severity of the recession and meet-full-need status, respectively. In Figure 5, we examine whether trends in SAT score sending to students' home state's flagship are correlated with those differential price increases.

The upper plot of Figure 5 shows that between 2006 and 2013, the percent of students sending an SAT score to the public flagship declined in all states regardless of the severity of the recession. The decline is more than twice as large, though, in states where the state unemployment rate increased by more than 5 percentage points relative to other states (a 12 percentage-point drop rather than a 5 percentage-point drop). These data are consistent with a significant score-sending response to the larger increase in tuition and fees in states where the recession was more severe. Of course, these descriptive patterns are also consistent with the direct impact of the recession on family income and the ability to afford a college education regardless of public flagship pricing decisions. We address this complication subsequently in our full econometric analysis.

The lower plot shows that declines in scores sent to flagships were also larger for states that meet full financial need. In combination, Figures 3, 4, and 5 provide preliminary evidence that students respond to changes in tuition by reducing the likelihood of "applying” (i.e. sending SAT scores) to public flagship institutions. We pursue this further in a more fully specified econometric model below.

The next relevant question is whether price sensitivity is different among financial aideligible and financial aid-ineligible students, particularly distinguishing public flagships by meetfull-need status. Aid-eligible students should not be price sensitive at meet-full-need schools 
(here, and throughout the remainder of the discussion, we will use the labels MFN and not-MFN schools to distinguish their meet-full-need status).

We provide preliminary evidence on this point in Figure 6. In this figure, the Y-axis measures the difference in the likelihood of sending scores to public flagships between MFN and not-MFN schools. We know from Figure 3 that prices increased more at MFN schools following the financial crisis. Among “aid-ineligible” students (defined as students residing in a highincome zip code where median family income is greater than $\$ 75,000$ per year) who are largely subject to those price increases, we may then expect to see a decline in scores sent to MFN schools relative to not-MFN schools when prices jumped starting in 2010. That is exactly what we see in Figure 6 (orange line - note that the difference in scores sent between types of schools is normalized to zero in 2006). There is around a 4-percentage point drop in scores sent between 2010 and 2011 for “aid-ineligible” students at MFN schools compared to non-MFN schools.

We repeat this analysis for "aid-eligible” students in Figure 6, with the results displayed in the blue line (again, differences in scores sent between MFN and not-MFN schools are normalized to zero in 2006). We also see a decline in scores sent to MFN schools relative to notMFN schools right at the point that relative prices jumped at MFN schools. The reduction in scores sent between 2010 and 2011 is somewhat smaller, around 3 percentage points for this group, but still noticeable. Nonetheless, “net prices” after factoring in financial aid would likely have been unaltered for students in this group. We would have expected to see no change in score sending behavior for students at MFN schools but declines in score sending at not-MFN schools. Consequently, the difference should have narrowed. Instead, the difference increases. This provides preliminary evidence consistent with sticker shock. Again, we pursue this further in a more fully specified econometric model below.

We have repeated this analysis for enrollment rates, describing patterns in enrollments by MFN and by the magnitude of the recession in much the same way that we did in Figures 5 and 6. No obvious patterns exist in these data (see Appendix Figures A.2 and A.3). We provide a 
more complete discussion of enrollment outcomes when we present the results from our complete econometric analysis.

\section{Formal Testing for Sticker Shock}

\subsection{Empirical Specification}

The descriptive figures are informative but do not exploit the full extent of price variation over this time period. Additionally, they do not control for changing demographics of SAT takers in the state or local economic conditions which could impact score sending to the flagship. The discussion that follows focuses specifically on the outcome of score-sending behavior, but it applies directly to the subsequent analysis on enrollment decisions.

We start by estimating the score send response to tuition among all students with the following model:

$$
S_{i c s t}=\beta_{1} \ln T_{s, t-1}+\beta_{2} U_{c, t-1}+X_{i} \Gamma+\alpha_{t}+\alpha_{s}+\varepsilon_{i c s t}
$$

where $S_{\text {icst }}$ is an indicator that equals 1 if student $i$ from county $c$ in state $s$ in graduation cohort $t$ sent a SAT score report to her public flagship institution, $\ln T_{s, t-1}$ is the $\log$ of real tuition and fees at public flagship $s$ in academic year $t-1, U_{c, t-1}$ is the unemployment rate in student i's county in calendar year $t-1, X_{i}$ is a matrix of student covariates (verbal and math SAT scores, parental education indicators, race indicators, female indicator, percent of the state's high school graduates taking the SAT and sending a score report, median family income in her zip code, and an indicator for residing in low-income zip code), $\alpha_{t}$ are cohort fixed effects, and $\alpha_{s}$ are state (school) fixed effects. ${ }^{23}$ We cluster standard errors at the state (school) level.

In addition to estimating equation (1) by OLS, we also estimate an IV regression to address the potential endogeneity of tuition and fees. We follow the lead of Deming and Walters (2017) and use state budget shocks as our instrument. Technically, state budget shocks are defined as

\footnotetext{
${ }^{23}$ Note that state fixed effects are equivalent to school fixed effects because we have one public flagship per state. We have also estimated analogous models that also include all state universities that meet full need even if they are not flagships. These include eight other University of California schools along with William and Mary in Virginia. Our results are qualitatively similar than those we report here. We have chosen to present results using one flagship per state because it lessens the heavy weight placed on just the California schools.
} 


$$
Z_{i t}=\frac{\text { state appropriations }_{s t}}{\text { student population }_{s t}} \times \frac{\text { state appropriations }_{S(2005)}}{\text { school total revenue }_{S(2005)}}
$$

The first term captures annual changes in state spending per student at each institution. ${ }^{24}$ The second term reflects how important state appropriations were to a school's total revenue, with both values measured in 2005. That baseline period occurred prior to the sample used in our study and is chosen as an exogenous measure of state support to each flagship institution. If a state experienced a more severe recession and faced greater spending cuts to higher education, that would matter more for schools that receive a larger share of their spending from the state.

In combination, it measures the budget shock a school experiences if state appropriations are cut, which they were during the recession. We measure the state budget shock in year $t-2$, the academic year prior to when the academic year $t-1$ tuition rate is set as the instrument (see Appendix 1 for a full discussion of timing issues and lag lengths in our analysis). Importantly, we also control for the county unemployment rate to capture direct local effects of the recession which could impact family finances and college-going. The first stage in this IV specification takes the form:

$$
\ln T_{s, t-1}=\gamma_{1} Z_{s, t-2}+\gamma_{2} U_{c, t-1}+X i, \Theta+\delta_{t}+\delta_{s}+u_{i c s t}
$$

Although we use a Deming and Walters-style instrument, we note an important distinction between our work and theirs. We focus only on the 2006 through 2013 period. ${ }^{25}$ The impact of the financial crisis on school budgets, which began in the 2009-10 academic year was by far the largest factor influencing state budgets during this period. State variation in the severity of the recession provides an important source of exogenous variation on its own, reducing the potential influence of endogenous pricing decisions. The sensitivity of our results to using IV instead of OLS may be limited because of this.

Our focus on state flagship institutions also alleviates one other concern that the Deming and Walters' research raises regarding our analysis. These authors find that state budget shocks

\footnotetext{
${ }^{24}$ Our measure of student population is the number of high school seniors graduating in year $t$.

${ }^{25}$ The considerably shorter sample period that we use also prevents us from extending our analysis to introduce Deming and Walters' alternative instrument, caps and freezes on state tuition. We experimented with this approach, but we found too little power in our first stage to implement this approach.
} 
also affect spending at higher education institutions, not just tuition. This would cause a problem in our analysis because we may be conflating sticker shock, which should only affect some groups of students, with "spending shock,” which would affect all students. Bound, et al. (2019) also examine this issue and find support for a relationship between business cycle conditions and spending at higher education institutions, in general. They also find, though, that researchintensive universities, like state flagships, do not adjust their spending in response to state budget shocks. We also conducted our analysis that supports this conclusion.

The aggregate analysis represented by equation (1) does not inform the question of whether sticker shock occurs. Our test of sticker shock is based on the differences in estimated elasticities between "aid-eligible” and "aid-ineligible” students in states that do and do not meet full financial need. To estimate these elasticities, we estimate a triple-difference specification of the form:

$$
\begin{aligned}
& S_{i c s t}=\beta_{1} \ln T_{s, t-1}+\beta_{2} \ln T_{s, t-1} \times E_{i}+\beta_{3} \ln T_{s, t-1} \times M F N_{s}+\beta_{4} \ln T_{s, t-1} \times E_{i} \times M F N_{s} \\
& +\beta_{5} M F N_{s} \times E_{i}+\beta_{6} M F N_{i}+\beta_{7} M F N_{s}+\beta_{8} U_{c, t-1}+X i, \Gamma+\alpha_{t}+\alpha_{s}+\varepsilon_{i c s t}
\end{aligned}
$$

where $E_{i}$ is an indicator that equals 1 if student $i$ resides in a lower income zip code (a proxy for financial aid eligibility), and $M F N_{s}$ is an indicator for whether the public flagship in state meets full need. Note that the $E_{i}$ main effect is included in $X_{i}$. The triple difference reflects changes in the likelihood of sending s score between high sticker shock and low sticker shock states (first difference), students in meet full need and not-meet-full need states (second difference) and lowincome status (third difference).

Adding the appropriate coefficients provides the overall effect of a tuition increase for four different groups of students: “aid-ineligible” students in not-MFN states ( $\left.\beta_{1}\right)$, “aid-eligible” students in not-MFN states $\left(\beta_{1}+\beta_{2}\right)$, “aid-ineligible” students in MFN states $\left(\beta_{1}+\beta_{3}\right)$, and “aideligible” students in MFN states $\left(\beta_{1}+\beta_{2}+\beta_{3}+\beta_{4}\right)$. These estimates can be converted into elasticities by dividing by the mean rate of score sending within each group. 
If "aid-eligible" students are aware of net prices and respond accordingly, we should find that their elasticity is 0 . In other words, whatever impact higher sticker prices have on score sending for the other groups of students (i.e. $\beta_{1}+\beta_{2}+\beta_{3}$ ) should be completely counteracted by the fact that "aid-eligible" students in MFN states are the only group that face no net price increase when sticker tuition rises (i.e. $\beta_{1}+\beta_{2}+\beta_{3}=-\beta_{4}$ ). If this is not true and if the elasticity for this group is negative and significant, it would provide evidence of sticker shock. In fact, if $\beta_{4}$ $=0$, then students in this group would fully incorporate the sticker price change the same way that other groups do despite the fact it does not apply to them.

\subsection{Score Sending Results}

Table 1 reports the estimated coefficients obtained from the models described in equations (1) through (3). Table 2 uses the coefficients from Table 1 to estimate the absolute impact of a tuition increase on the probability of sending SAT scores to students' own states' public flagship institution. It also converts these estimates to elasticities.

The first row of Table 1 corresponds to the estimates using scores sent from all students. The OLS estimate indicates that a 10 percent increase in tuition and fees at the public flagship decreases the probability that an SAT taker from that state sends a score to the public flagship by 1.8 percentage points (a 5.4 percent decrease relative to the mean score-sending rate of 33.7 percent). This corresponds to a price elasticity of -0.54 , reported in Table 2 . The IV estimate is similar, leading to a 1.2 percentage point reduction in score sending and a price elasticity of score sends of -0.35 . These results suggest that the demand curve for college applications, as measured by SAT score sends, is downward sloping, but inelastic.

The remainder of Tables 1 and 2 reports the estimated coefficients from the triple difference specification represented by equation (3) and the associated elasticities by group. All interacted coefficients are small and statistically insignificant, including the triple interaction. In 
OLS, the estimated impact is similar across all groups. The IV estimates are mainly consistent with OLS, but less precise in this specification.26 The estimated impact for aid-ineligible students in states that do not meet full need is smaller in an absolute sense, but it is not estimated precisely enough to statistically distinguish it from the other groups. In both OLS and IV, we cannot reject the null hypothesis that absolute impacts are equal. Elasticities are somewhat bigger (although not significantly different) for students in MFN states, which is attributable to similar point estimates, but lower mean rates of score sending.

Importantly, the estimated absolute impact and elasticity for "aid-eligible” students in MFN states is negative and statistically significant (the p-value on the absolute impact is very small in OLS and equal to 0.033 in IV). This indicates that "aid-eligible” students in MFN states are less likely to send scores to public flagships when tuition increases, which is consistent with sticker shock. As discussed earlier, the actual net price paid by these students would not change with an increase in tuition.

\subsection{Heterogeneity in Responsiveness to Tuition Increases}

We also consider whether any heterogeneity exists in the results across population subgroups that may be differentially affected by sticker shock in the application decisions to public flagship institutions. Of course, differences in behavioral responsiveness to price changes across groups is a possibility, but a simpler explanation would be the underlying propensity to apply to one of these schools in the first place. If a student is less interested in applying to a school in the first place, that student is less likely to respond to a price increase by withholding their application.

\footnotetext{
${ }^{26}$ There are currently no tests for weak instruments in the case of multiple endogenous regressors with non-i.i.d errors (Baum et al., 2007). However, we follow the advice of Baum et al. (2007) and nevertheless report the Kleibergen and Paap Wald Rank F test statistic in Table 1 for our triple difference specification (Kleibergen and Paap, 2006). This statistic cannot be compared to the usual Stock-Yogo weak id test critical values because the Stock-Yogo values assume i.i.d errors. Critical values have not yet been tabulated for the Kleibergen-Paap rk statistic since the thresholds depend on the type of violation of the independent and identically distributed assumption, which differ across applications (Bazzi and Clemens, 2013). Angrist and Pishke (2009) show using Monte-Carlo simulations that two stage least squares is approximately median-unbiased in the just-identified case even with weak instruments, so we believe weak instruments bias is unlikely to be a problem in our setting.
} 
In our analysis, we separate students into population subgroups with different underlying propensities to apply to a public flagship. We measure these propensities by the average SAT score send rate for the 2006 through 2008 cohorts who graduated from high school before the tuition price spikes brought about by the financial crisis. We distinguish two groups that are more likely to apply to a public flagship - students whose combined math and verbal SAT scores are above the state-specific flagship "median" among enrolled student ${ }^{27}$ and students who have a parent who graduated from college. In our data, 45.6 percent and 41.0 percent of these students from the 2006 through 2008 cohorts who took the SAT sent their scores to a public flagship, respectively. We also distinguish students by race/ethnicity, separating them into categories of white, underrepresented minorities (black or Hispanic), or Asian. Among these three groups, our baseline SAT score send rate to public flagships is highest for Asian students (51.6 percent) and lowest for underrepresented minorities (32.2 percent).

The results of our analysis are reported in Table 3. We report absolute impacts on the probability of sending SAT scores to a public flagship in response to tuition increases, using OLS and IV as before. Across all these groups, we see results similar to our earlier findings that the responsiveness of score sending to tuition increases is generally comparable regardless of aid-eligibility and the MFN status of the public flagship in the student's state of residence. Sticker shock appears to be a problem for all population subgroups.

Yet the absolute impact of the score send response is different across groups. Our analysis yields point estimates that are largest for students with high SAT scores and for Asian students. These groups have the highest baseline propensity to apply to a public flagship.

\subsection{Specification Checks}

Our identification strategy relies strongly on the potential differential response of "aideligible" students in states whose flagships meet full need in their financial aid policies. If this group of students responds to price increases the same way as other students, that represents sticker shock. But it is important to note that having an MFN financial aid policy is not randomly

${ }^{27}$ The "median" is defined as the midpoint between the $25^{\text {th }}$ and $75^{\text {th }}$ percentiles, based on data available from IPEDS. 
assigned across state flagship institutions. Indeed, the schools that have these policies tend to be those that have higher academic standards as measured by the average SAT scores of their accepted students. Based on IPEDS data, the four MFN flagship institutions (UC Berkeley, Michigan, North Carolina and Virginia) are all in the top 10 of the average SAT distribution among flagship institutions. School/state-specific fixed effects address long-term differences in application and enrollment behavior, but one could imagine that students respond to price changes at more selective schools differently than they would at other schools. An alternative interpretation of our results might be that it is capturing the impact of differential price elasticities at more selective flagships relative to others as opposed to differences by MFN status.

We examine this possibility by restricting our sample to the subset of schools with median combined SAT scores (as defined earlier) above 1200; 17 state flagship institutions meet this criterion. ${ }^{28}$ This approach reflects a crude way to restrict the sample to just the "elite" flagships. If we estimate the same specifications as described earlier just for these schools and obtain similar results, then MFN status is unlikely to be acting as a proxy for "elite" status in interpreting those results.

The elasticities obtained from this analysis are provided in Table 4. Because we are only including 17 states in this analysis and clustering our standard errors by state, we report p-values from traditional clustering by state and those obtained using a wild bootstrap approach. The smaller sample size and the use of a wild bootstrap technique to conduct statistical inference generates results that are less precise than in the full analysis, particularly in the IV models. Overall, though, our results are broadly consistent with those reported earlier for the full sample of states. The demand elasticity point estimates are somewhat smaller in the "elite" school sample, but we would not be able to statistically distinguish them from the full sample. More importantly, the demand elasticities across groups are similar and statistically indistinguishable from each other. Greater precision would improve our interpretation of these results, but we see no evidence based on this analysis to lead us to question the interpretation of our earlier results.

\footnotetext{
${ }^{28}$ The states represented include: CA, CT, FL, GA, IA, IL, KS, MA, MD, MI, MN, NC, NJ, OH, TX, VA, and WI.
} 
Another potential issue in interpreting our results is that we restrict our sample to those students who sent any SAT scores, and those students may reflect a selected sample. It is possible that SAT score senders are more likely to respond to changes in sticker prices or, in IV models, state economic conditions, than non-senders. To gauge whether this form of selection is a relevant issue, we estimate OLS and IV models of SAT score sending among the population of SAT takers (including non-senders) in the College Board database. We find no evidence that score sending probabilities are affected by tuition at public flagships. ${ }^{29}$

Another specification check examines the sensitivity of our results to alternative measures of aid-eligibility status. Our median family income in the student's zip code measure is imperfect in that some higher income families still reside in relatively low median income zip codes and vice versa. We estimated several alternative measures of likely aid-eligibility to test the sensitivity of our results. Instead of zip codes with median family income below $\$ 75,000$, we also tried analogous measures with different values of median family income $(\$ 50,000$ and \$100,000). We also experimented with student-reported family income and parental education to distinguish those who are likely to be eligible for financial aid. The results of these analyses are reported in Table A.2. They all yield similar estimates of the impact of tuition increases on scores sent to public flagship institutions. ${ }^{30}$

\footnotetext{
${ }^{29}$ We also tried to examine whether SAT taking is endogenous. Since the College Board collects data on any student interacting with them, including PSATs and AP exams, its data extends beyond those who take the SAT. We have estimated models comparable to those described in equations (1) through (3), but used the full sample of students in the College Board database and excluded the explanatory variables that are only available for SAT takers (like SAT scores) or only widely reported for SAT takers (like parental education). The results using the more limited set of controls indicate that increases in tuition brought about by changes in state economic conditions are correlated with changes in the number of students who take the SAT. The question for us is whether those tuition increases lead to a reduction in the number of students who take the SAT and would be applying to a state flagship otherwise. The group of students on the margin of taking the SAT due to changes in state tuition are probably not marginal for applying to a flagship, so we believe this does not present a problem for our empirical strategy.

${ }^{30}$ We have also estimated models using a continuous measure of financial-aid eligibility based on the probability that a student's family income is below \$75,000 using this zip code-level measure of median family income. The results are qualitatively similar to those reported below. We chose to report the discrete version because it is more easily interpretable in a quasi-experimental framework.
} 
We also consider the ACT as a substitute for the SAT as an additional specification check. An "application" in our data is sending an SAT score to a school, but in some parts of the country, that is unlikely just because the ACT is much more common. A student in one of those areas who takes and sends SAT scores may be selected in some non-random way that could have an impact on our results. To test this hypothesis, we restricted our sample to students residing in states where SAT score-sending rates are the highest - a third or more of a high school graduation cohort take the SAT. This occurs in about half the states. The results of this analysis are also reported in Appendix Table A.2; the responsiveness of SAT score sends to changes in tuition are no different in this sample of the students.

We also report in Table A.2 an additional specification check that examines the influence that California plays in driving the results. As the most populous state and the protests that resulted following the announced tuition increases, perhaps the aggregate price sensitivity is driven solely by UC Berkeley. We explore this possibility by simply dropping Berkeley from the sample. Again, we find our results to be strongly robust to this sample restriction. ${ }^{31}$

The final set of specification checks we report addresses how score sending responds to changes in cost of attendance rather than tuition and fees. The cost of attendance represents tuition and fees plus other components of costs (room and board, transportation and personal expenses, and books and supplies). If, as we argue in section 2.4, students respond to changes in tuition because that is what is publicized, then incorporating these other elements of cost introduces a random component to our key explanatory variable. In terms of our IV strategy,

\footnotetext{
${ }^{31}$ We do note, however, that IV estimates become very unstable when we drop California from the sample because there appears to be too little variation in labor market conditions across other meet full need states to provide sufficient identification.
} 
these additional elements of cost (which are typically set by the campuses, not the state) are also less affected by state budget conditions, weakening our identification strategy.

The results of our analysis using COA rather than tuition and fees, shown in Table A.3, support these propositions. OLS estimates for all students are similar between the COA and tuition and fees specifications, but the results by MFN status and aid eligibility are considerably less precisely estimated. In the IV models, the state budget shock instrument is a weaker predictor of COA compared to tuition and fees; the F-statistic from the first stage fell from 20.8 to 4.87. Consequently, our results for the impact of changes in COA on score-sending are much noisier than the results for the impact of changes in tuition and fees in the aggregate and in models broken down by MFN status and aid eligibility. Overall, we believe this analysis supports our preference to focus on tuition and fees in this analysis.

\section{Impact on Enrollments}

If students respond to changes in college pricing with full information regarding their actual financial impact, then a tuition increase has the potential to increase socioeconomic diversity at MFN colleges. At these schools, low- and moderate-income students are protected from those tuition increases and should not reduce their likelihood of applying. Those at other schools and higher-income students will all face the higher cost and could reduce their likelihood of applying. What we just saw, however, is that these students responded to an increase in the sticker price the same way as others even though it did not affect them. Applications of all students declined in response to tuition increases, regardless of their aid eligibility or their state flagship’s MFN status.

This raises the question of where they eventually enrolled? If all students, including aideligible students in states whose public flagship meets full need, are less likely to apply to those 
flagships, what impact does that have on enrollments at those institutions and other institutions with which they compete? We can use similar methods to those described earlier to address this question. We simply replace the dependent variable, using enrollment rather than application. For this exercise, we use the National Student Clearinghouse data for the same students included in our application analysis.

Before reporting the results of this analysis, we note that the likely estimated impact on enrollments, if any, will be smaller than that on applications since only a relatively small percentage of applicants to public flagships are accepted and enroll. Even if some students did not apply because of the price increase, they may not have been accepted anyway, reducing the potential impact on enrollment. The smaller estimated impact also creates a power issue, particularly in our IV specifications. With smaller anticipated effects and the larger standard errors associated with them (based on the properties of the binomial distribution), it becomes much more difficult to generate results precise enough to reject the null hypothesis of no effect.

Indeed, our attempts to estimate IV models of the same form as earlier generated mainly insignificant coefficients. We report only OLS estimates in the remainder of this discussion as a result. Despite this limitation, it is important to keep in mind that OLS and IV estimates in our analysis of flagship applications were similar albeit slightly larger. Endogeneity in tuition setting does not seem like a major problem during our sample window, but it may have a minor influence on our results.

The first issue we address is whether enrollments change at all at public flagships. As the most competitive public institution in the state, these schools receive considerably more applications than students who are accepted. A reduction in applications does not necessarily 
generate a reduction in enrollment. They can always adjust their admissions standards to maintain it.

In fact, this is what we see. The first row of Table 5 reports the estimated impact on overall enrollment at public flagships in response to changes in tuition. We find no statistically significant changes in flagship enrollment in the aggregate and by MFN status or aid eligibility. This result is consistent with Barrow and Davis (2012), Long (2015), and Charles, Hurst, and Notowidigdo (2018) who show strong evidence of cyclicality in college enrollments at two-year public institutions and for part-time enrollments at four-year public institutions, but the impact on full-time enrollments at four-year public institutions is clearly smaller or perhaps nonexistent.

To determine the extent to which this result is attributable to changes in selectivity, we examine the impact of changes in sticker prices on the combined math and verbal SAT scores of enrolled students who sent their SAT scores to the flagship. The second row of Table 5 reports the results of estimating models that are identical in specification except that the dependent variable is now the combined SAT score of enrolled SAT score-sending students at public flagships. The results indicate that a tuition increase reduces those scores. A 10 percent increase in tuition leads to a 2.2 point drop in combined SAT scores in the aggregate. The differences in effects by MFN and aid-eligibility status are small and not statistically significant.

We extend this analysis by focusing solely on "high-achieving” students, whose SAT scores are above the “median” (midpoint of the $25^{\text {th }}$ and $75^{\text {th }}$ percentile) of enrolled students at each institution. For these students, in OLS specifications we see a statistically significant reduction in enrollment; overall, a 10 percent increase in tuition leads to a 0.7 percentage point decline in enrollments among this group. These past two sets of results support the conclusion 
that public flagships maintained their enrollment after increasing their prices during the recession by lowering admissions standards.

This raises the question of where high-achieving students who otherwise would have enrolled in their home state's public flagship end up enrolling? One possibility is that they could have chosen to reduce their college cost by living closer to home and attending a non-flagship 4year state university. ${ }^{32}$ Identifying the impact of flagship tuition on public, non-flagship enrollment, however, is complicated because flagship and non-flagship tuition are both set within the context of the same state's budgetary environment and are often determined through a similar process. Indeed, the correlation in tuition between flagships and non-flagships across states and years in our data is 0.91 . Non-flagships do not necessarily have the same excess supply of applicants to maintain enrollment if a price increase reduces demand. If increases in flagship tuition is matched by tuition increases in non-flagship institutions, then we would expect to see a reduction in enrollments at those institutions, not an increase associated with substitution. In other words, the results of this analysis would have a negative bias.

By restricting our sample to high-achieving students, though, this should be less of a problem. In our data, high achievers are 2.5 times more likely to attend a public flagship than a public non-flagship institution (17.0 percent versus 6.8 percent). By restricting our sample to just high achievers, we reduce the bias associated with the correlated prices and can better identify substitution. The results of this analysis are reported in the fourth row of Table 5 . We find no statistically significant change in the enrollment of high achievers at public non-flagships in response to a tuition increase.

\footnotetext{
32 High-achieving students are very unlikely to attend community college; just 2.1 percent do so in our sample. Perhaps because of this, we find no evidence of substitution to these institutions.
} 
The remainder of the table considers the impact on other enrollment options among highachieving students. We consider the following alternatives: out-of-state flagship institutions, four-year private non-profit institutions, and the subset of those institutions that have "meet full need" financial aid policies. The final category is likely to have the lowest cost of attendance for lower income students, but they are not that common and typically highly selective. We note that the huge jump in tuition at public institutions during the financial crisis was not matched by tuition increases at private institutions (Ma, et al., 2018), suggesting that identifying the crossprice effect is easier here than in the case of public non-flagships. Own-price effects are adequately controlled for with year fixed effects since private non-profit institutions tend to have national (or at least regional) markets. Competition across those institutions also restricts local differences in price variation over time. Similarly, the out-of-state flagship market is a national one, so year fixed effects will capture the average effect of price changes at those institutions.

The results indicate that high achievers are more likely to attend a private non-profit 4year institution when public flagship prices rise. A 10 percent increase in tuition at public flagships increased enrollment of these students at these private colleges by 0.8 percentage points. This roughly matches the decline in enrollment of high achievers at public flagships. We also see modest evidence of increases in enrollments at out-of-state flagships and MFN private institutions, but those effects are spotty and considerably smaller.

\section{Discussion}

Price discrimination in the form of high sticker prices with generous financial aid for lower-income students is a common pricing strategy at selective universities across the United States. In theory, this pricing strategy can maximize tuition revenue while maintaining access for lower-income students because generous financial aid awards keep prices affordable. However, if students are unaware that they will qualify for financial aid and are discouraged from applying 
based on high sticker prices, this pricing strategy may not have its intended effect of increasing access to higher education.

In this paper, we examine the existence of sticker shock using exogenous variation in sticker prices at state flagship universities during and after the 2008 financial crisis. Using data on SAT score sends corresponding to students in the high school classes of 2006 to 2013, we investigate whether low- and moderate-income students in states where flagship institutions meet full financial need responded to price increases by reducing their application rates. Notably, in these states, those students would have been fully insulated from sticker price increases. Yet we find that they apply less often, similar to higher-income students and those living in states that do not meet full need. These results suggest the existence of important informational frictions.

Interestingly, had low- and moderate-income students not exhibited sticker price shock, tuition price increases during the 2008 financial crisis would have led to significantly greater socioeconomic diversity at the public flagships that meet full need. As higher-income students experienced actual price increases and reduced applications to the flagships, unaffected low- and moderate-income students would not have adjusted their application behavior. Consequently, they would have constituted a larger share of the applicant pool and proportion of admitted students. However, our results indicate this did not occur.

Our results have important implications for public policy. One common proposal to address the complexity of the financial aid system is to simplify the Free Application for Federal Student Aid (FAFSA), which is used to determine a student's eligibility for Pell Grant and other forms of financial aid (cf. Scott-Clayton and Dynarski, 2007).33 Though simplifying the FAFSA might increase participation in the financial aid system and college enrollment more generally, it may not go far enough to eliminate sticker price shock. To get students to apply in the first place, they need the ability to better forecast what their college costs will be at an early stage of the

\footnotetext{
${ }^{33}$ This is the system that is used for calculating financial aid at most, but not all, public flagship institutions. Many private colleges also require the CSS Profile - simplifying FAFSA would have no impact on schools that rely on that method for determining ability to pay.
} 
admissions process to overcome sticker shock. We need to find better ways to communicate pricing information and the availability of financial aid to complete students' understanding of what college will really cost them so that they can make informed educational decisions. 


\section{References}

Adams, C. J. (2017). "In race for test-takers, ACT outscores SAT-for now.” Education Week. https://www.edweek.org/ew/articles/2017/05/24/ in-race-for-test-takers-act-outscores-sat-for.html.

Angrist, J. and Pischke, J.S. (2009). "A Note on Bias in Just Identified IV with Weak Instruments.” http://econ.lse.ac.uk/staff/spischke/mhe/josh/solon_justid_April14.pdf

Asimov, N. (2009). “UC president recommends huge tuition increases.” San Francisco Chronicle. https://www.sfgate.com/education/article/ UC-president-recommends-hugetuition-increases-3218630.php.

Barrow, L. and Davis, J. 2012. "The upside of down: Postsecondary enrollment in the Great Recession.” Economic Perspectives, 36(4): 117-129.

Baum, C. F., Schaffer, M. E., and Stillman, S. (2007). "Enhanced routines for instrumental variables/generalized methods of moments estimation and testing.” The Stata Journal, 7(4): 465-506.

Bazzi, S. and Clemens, M. A. (2013). "Blunt Instruments: Avoiding Common Pitfalls in Identifying the Causes of Economic Growth.” American Economic Journal: Macroeconomics, 5(2): 152-186.

Bettinger, E., Terry Long, B., Oreopoulos, P., and Sanbonmatsu, L. (2012). "The role of application assistance and information in college decisions: Results from the H\&R Block FAFSA experiment.” Quarterly Journal of Economics, 127(3):1205-1242.

Bleemer, Z. and Zafar, B. (2018). "Intended college attendance: Evidence from an experiment on college returns and costs.” Journal of Public Economics, 157:184-211.

Bound, John, Breno Braga, Gaurav Khanna, and Sarah Turner (2019). "Public Universities: The Supply Side of Building a Skilled Workforce.” RSF: The Russell Sage Foundation Journal of the Social Sciences, 5(5): 43-66.

Burd, S. (2017). High-merit-aid public flagships see substantial shifts to wealthier students. In Stephen, B., editor, Moving on Up? What a Groundbreaking Study Tells Us About Access, Success, and Mobility in Higher Education, pages 33-34. New America.

Charles, K. C., Hurst, E., and Notowidigdo, M. J. (2018). "Housing Booms and Busts, Labor Market Opportunities, and College Attendance.” American Economic Review, 108(10): 2947-2994.

Chetty, R., Friedman, J., Saez, E., Turner, N., and Yagan, D. (2017). “Mobility report cards: The role of colleges in intergenerational mobility.” Mobility Statistics and Student Outcomes by College and Birth Cohort. http://www.equality-of-opportunity.org/data/. 
Chetty, R., Friedman, J., Saez, E., Turner, N., and Yagan, D. (2020). “Income Segregation and Intergenerational Mobility Across Colleges in the United States.” Quarterly Journal of Economics, Forthcoming.

College Board (2018). Trends in College Pricing 2018. New York: College Board.

Deming, David J. and Walters, Christopher. R. (2017). “The Impact of Price Caps and Spending Cuts on U.S. Postsecondary Attainment.” NBER Working Paper No. 23736.

Duke, A. (2009). “University of California students protest 32 percent tuition increase.” CNN News. http://www.cnn.com/2009/US/11/19/california.tuition.protests/index. html.

Dynarski, Susan, C.J. Libassi, Katherine Michelmore, and Stephanie Owen (2018) “Closing the Gap: The Effect of a Targeted, Tuition-Free Promise on College Choices of HighAchieving, Low-Income Students. NBER Working Paper No. 25349.

Dynarski, Susan M. and Judith E. Scott-Clayton (2007). "College Grants on a Postcard: A Proposal for Simple and Predictable Federal Student Aid.” Hamilton Project Discussion Paper 2007-01.

Gordon, L. and Khan, A. (2009). “UC regents approve fee hike amid loud student protests.” Los Angeles Times. http://latimesblogs.latimes.com/lanow/2009/11/ uc-regents-approve-feehike-amid-loud-student-protests.html.

Gurantz, Oded, Jessica Howell, Mike Hurwitz, Cassandra Larson, Matea Pender, and Brooke White. (2019). "Realizing Your College Potential? Impacts of College Board’s RYCP Campaign on Postsecondary Enrollment.” (EdWorkingPaper: 19-40). Retrieved from Annenberg Institute at Brown University: https://edworkingpapers.com/ai19-40

Hemelt, S. V. and Marcotte, D. E. (2011). "The impact of tuition increases on enrollment at public colleges and universities.” Educational Evaluation and Policy Analysis, 33(4):435- 457.

Hoxby, C. and Avery, C. (2013). “The missing 'one-offs': The hidden supply of high-achieving, low-income students.” Brookings Papers on Economic Activity.

Hoxby, C. and Turner, S. (2013). "Expanding College Opportunities for High-Achieving, Low Income Students.” SIEPR Discussion Paper No. 12-014. https://siepr. stanford.edu/sites/default/files/publications/12-014paper_6.pdf.

Hoxby, C. and Turner, S. (2015). "What high-achieving low-income students know about college.” American Economic Review: Papers \& Proceedings, 105(5):514-517.

Huntington-Klein, N. (2016). "The search: The effect of the college scorecard on interest in colleges.” Unpublished Working Paper. Available at: 
https://www.aeaweb.org/conference/2017/preliminary/paper/hf7A8bfB, accessed 2/3/2020.

Hurwitz, M. and Smith, J. (2018). "Student responsiveness to earnings data in the college scorecard.” Economic Inquiry, 56(2):1220-1243.

Kleibergen, F. and Paap, R. (2006). "Generalized reduced rank tests using the singular value decomposition.” Journal of Econometrics, 133: 97-126.

Levine, P. B. (2014). “Transparency in college costs.” Brookings Institution. http://www.brookings.edu/research/papers/2014/11/12-transparency-in-college-costslevine.

Long, B. T. (2015). “The Financial Crisis and College Enrollment: How Have Students and Their Families Responded?” In Brown, J. and Hoxby, C.M. (Ed.) How the Financial Crisis and the Great Recession Affected Higher Education, University of Chicago Press.

Longmire \& Company. (2013). "Your Value Proposition: How prospective students and parents perceive value and select colleges.” https://www.longmireco.com/documents/studies/Value_Proposition_Study_Report.pdf

Ma, Jennifer, Sandy Baum, Matea Pender, and CJ Libassi (2018), Trends in College Pricing 2018, New York: The College Board.

Pallais, A. (2015). "Small differences that matter: Mistakes in applying to college.” Journal of Labor Economics, 33(2):493-520.

Sallie Mae (2016). "How America pays for college 2016. Sallie Mae's national study of college students and parents." https://news.salliemae.com/files/doc_library/file/ HowAmericaPaysforCollege2016FNL.pdf.

State Higher Education Executive Officers Association (2018). SHEF: FY 2018 State Higher Education Finance. Available at: https://sheeomain.wpengine.com/wpcontent/uploads/2019/04/SHEEO_SHEF_FY18_Report.pdf, accessed 1/7/2020.

The College Board and Arts \& Sciences Group (2012). studentPoll, 9(1).

Western Interstate Commission for Higher Education (2016). Knocking at the College Door: Projections of High School Graduates through 2032. Available at: https://knocking.wiche.edu/, accessed 1/7/2020.

Zinth, K. and Smith, M. (2012). "Tuition-Setting Authority for Public Colleges and Universities.” Education Commission of the States. https://www.ecs.org/clearinghouse/01/04/71/10471.pdf 
Figure 1: Estimated "Unmet Financial Need" at Public Flagships for Families with Household Income of $\$ 50,000$ and No Assets, Fall 2019

$\$ 20,000$

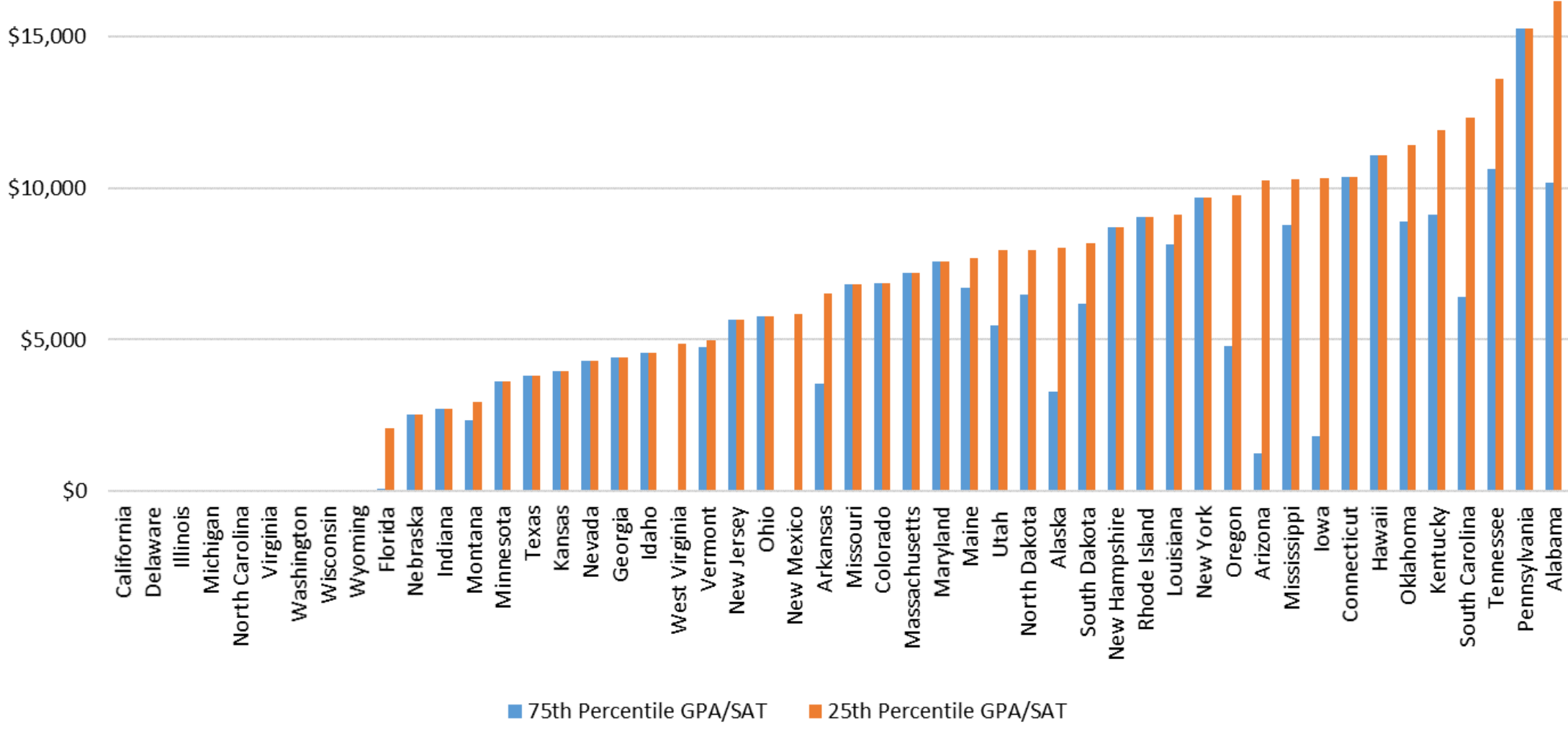

Notes: Authors calculations using output from net price calculators posted on public flagship websites in fall 2019. Self-help (loans and workstudy) is assumed to be $\$ 8,500$, except in California, that meets full need by packaging $\$ 9,500$ in self-help. Calculations assume no assets, a family of 4 with 2 married parents, each of whom makes $\$ 25,000$, and one child in college. For schools offering merit scholarships, unmet need is calculated for students at the 25th and 75th percentiles of the GPA and SAT distribution of enrolled students as reported in the school's 


\section{Figure 2: Annual Increase in Tuition and Fees at Public Flagships}

10

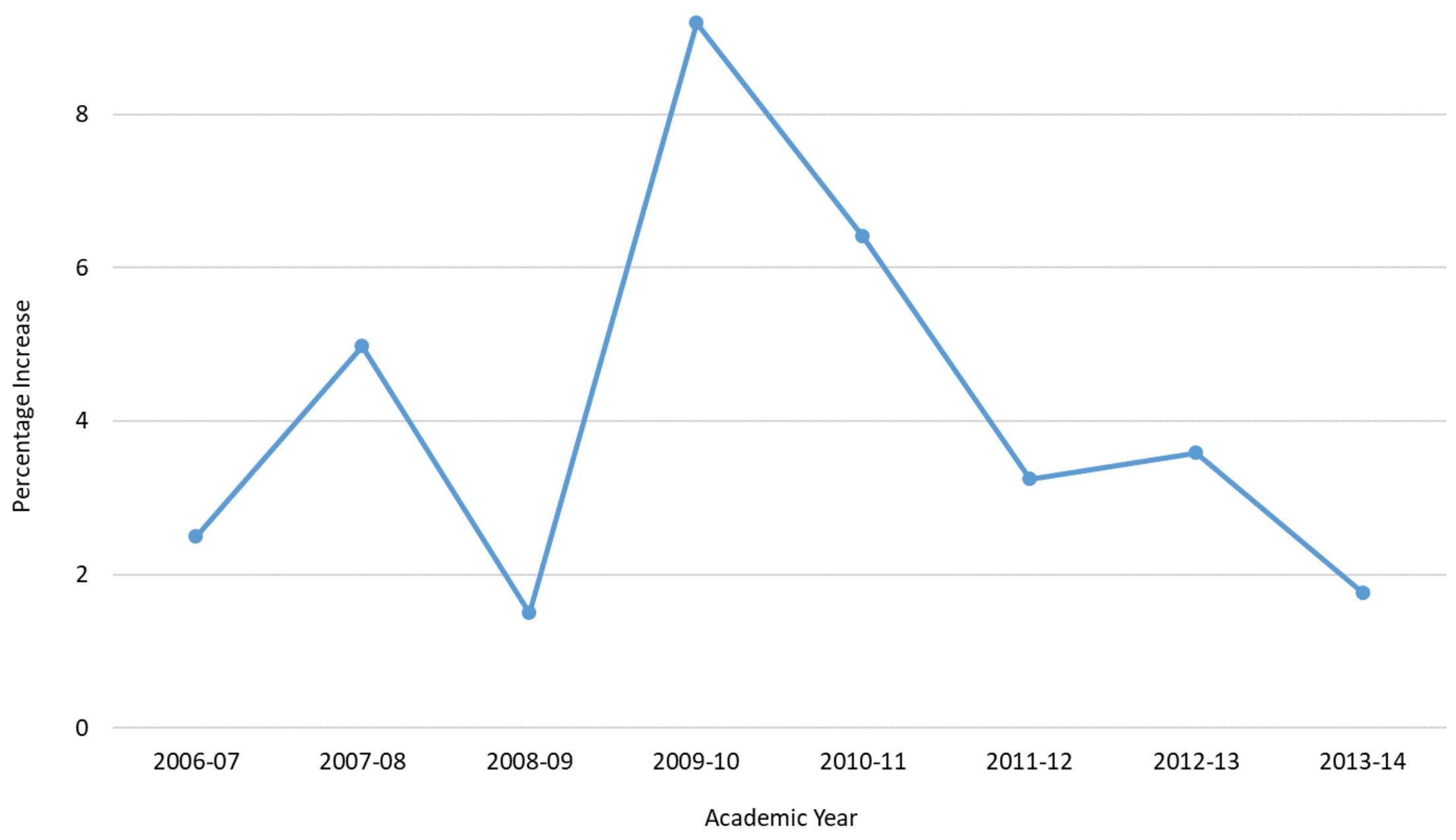

Notes: Data come from IPEDS and reflect increases in CPI-adjusted tuition and fees from 50 public flagships (UC Berkeley in California and UT-Austin in Texas). 
Figure 3: Annual Increase in Tuition and Fees at State Flagship Institutions, by Severity of the Recession

$20 \%$

$15 \%$

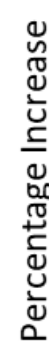

$5 \%$
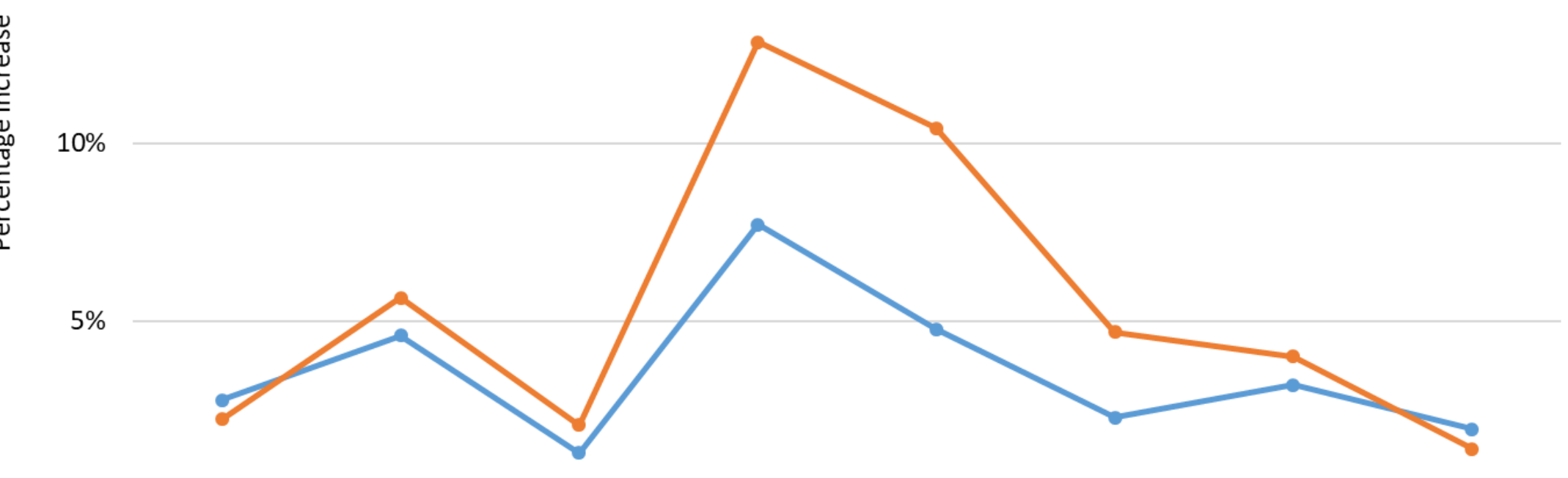

$0 \%$

2006-07

2007-08

2008-09

2009-10

2010-11

$2011-12$

2012-13

2013-14

Academic Year

Increase in State Unemployment Rate between 2008 and 2010

$\multimap$ less than or equal to $5 \% \multimap$ greater than $5 \%$

Notes: see notes to Figure 2. 
Figure 4: Annual Increase in Tuition and Fees at State Flagship Institutions, by Meets Full Need Status

$20 \%$

$15 \%$

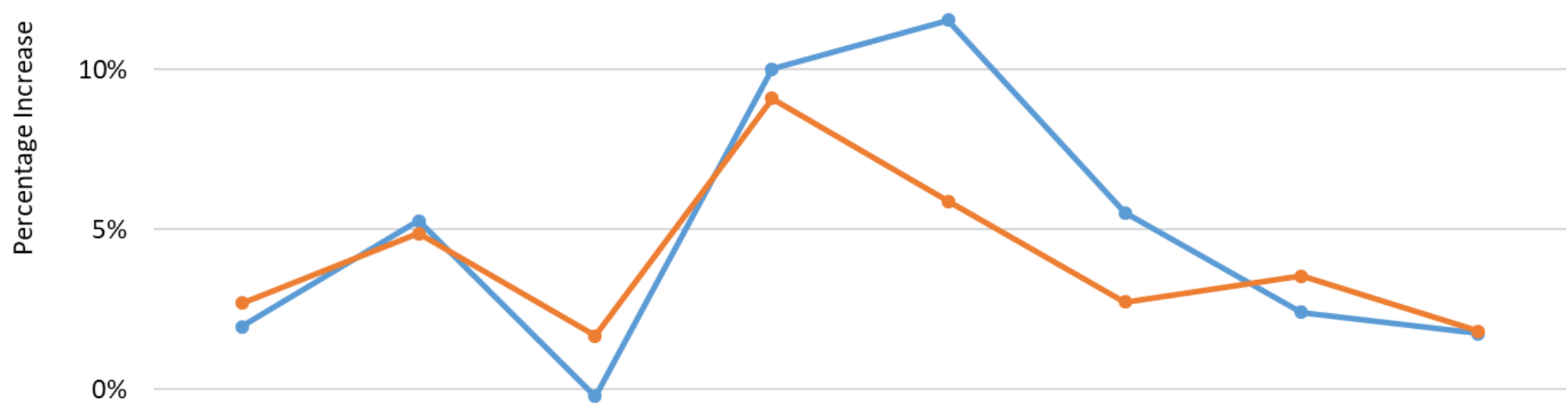

$-5 \%$

$\begin{array}{ccccc}2006-07 \quad 2007-08 & 2008-09 \quad 2009-10 \quad 2010-11 \quad 2011-12 \quad \text { Academic Year } \\ & \\ & \text { Meet Full Need } \quad-\text { Doesn't Meet Full Need }\end{array}$

Notes: see notes to Figure 2. 


\section{Figure 5: Trends in SAT Score Sending Rates to Flagship Institutions}

By Severity of the Recession

$45 \%$

$40 \%$

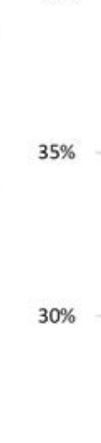

$25 \%$

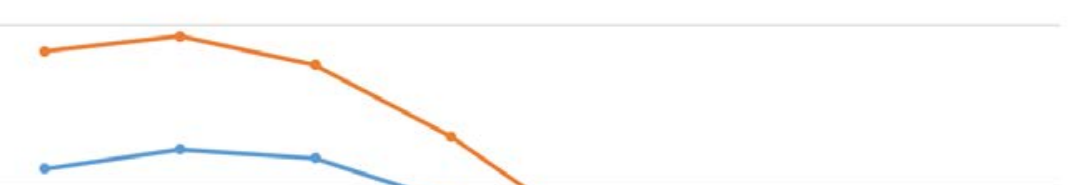

$5 \%$

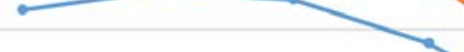

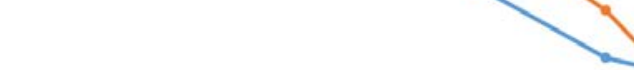

\%

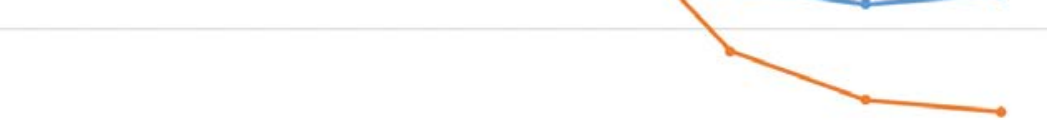

2006

2007

2008

$2009 \quad 2010$

201

High School Graduation Cohort

Increase in State Unemployment Rate between 2008 and 2010

$\rightarrow$ less than or equal to $5 \% \rightarrow$ greater than $5 \%$

By Meet-Full-Need Status

$45 \%$

$40 \%$

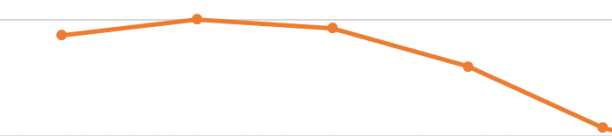

$35 \%$

$30 \%$

$25 \%$

$20 \%$
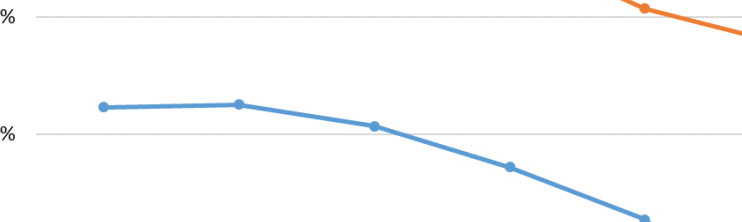

$\%$

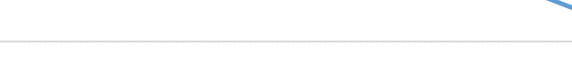

$15 \%$

2006

2007

2008

20092010

2011

201

2013

$\multimap$ Meets Full Need $\quad \bullet$ Doesn't Meet Full Need

Notes: Percent of students sending scores to flagship institution is defined as the percent of students appearing in the College Board SAT score send sample who send a score report to their home state's flagship. 
Figure 6: Difference in Rate of Sending Scores to Flagship Institutions, by Families' Aid-Eligibility Status and Schools' "Meet Full Need" Status

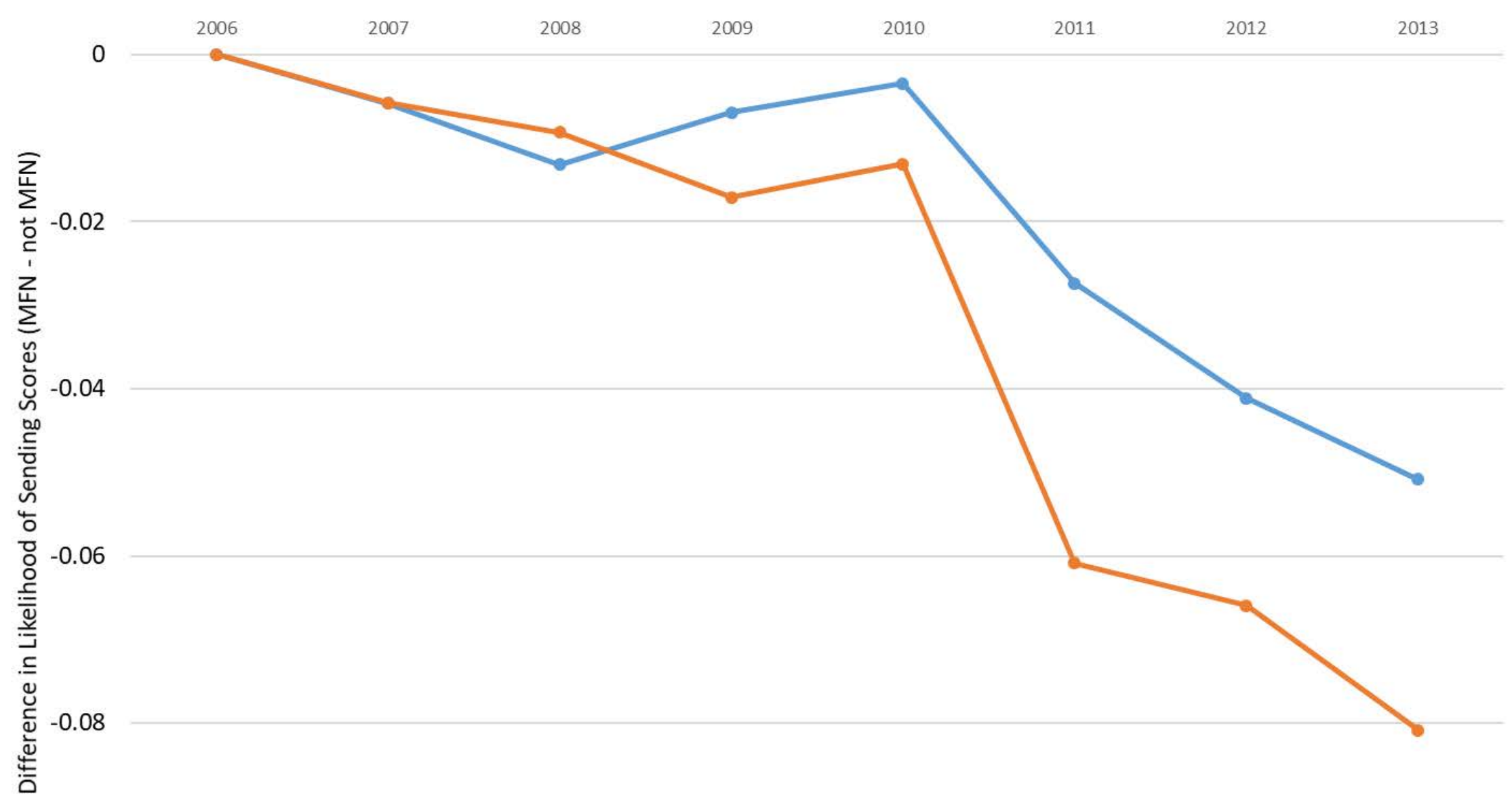


Table 1: Estimated Impact of Increases in Tuition and Fees on Likelihood of Students Sending SAT Scores to Public Flagship Institutions

\begin{tabular}{|c|c|c|}
\hline & OLS & IV \\
\hline \multicolumn{3}{|c|}{ Aggregate } \\
\hline $\begin{array}{l}\text { ln(in-state tuition and fees, } \\
\text { lagged one year) }\end{array}$ & $\begin{array}{l}-0.183 \\
(0.051)\end{array}$ & $\begin{array}{l}-0.119 \\
(0.061)\end{array}$ \\
\hline First Stage F-Statistic & --- & 20.8 \\
\hline \multicolumn{3}{|c|}{ Triple Difference } \\
\hline $\ln$ (tuition) & $\begin{array}{l}-0.180 \\
(0.041)\end{array}$ & $\begin{array}{l}-0.023 \\
(0.094)\end{array}$ \\
\hline ln(tuition*“aid eligible”) & $\begin{array}{c}0.033 \\
(0.038)\end{array}$ & $\begin{array}{l}-0.116 \\
(0.088)\end{array}$ \\
\hline ln(tuition*meet-full-need) & $\begin{array}{l}-0.047 \\
(0.036)\end{array}$ & $\begin{array}{l}-0.139 \\
(0.073)\end{array}$ \\
\hline ln(tuition*meet-full-need*“aid eligible”) & $\begin{array}{c}0.015 \\
(0.042)\end{array}$ & $\begin{array}{c}0.129 \\
(0.094)\end{array}$ \\
\hline Sample Size & $7,589,048$ & $7,589,048$ \\
\hline Kleibergen and Paap Wald Rank F Test & --- & 7.9 \\
\hline \multicolumn{3}{|c|}{$\begin{array}{l}\text { Notes: Estimates are obtained from a model of the form of equations } 1 \text { through } 3 \text { and based on } \\
\text { the authors' analysis of College Board data on scores sent to students' in-state flagship university } \\
\text { among those who took the SAT and sent at least one score report to any college. Additional } \\
\text { explanatory variables include: the students' SAT math and verbal scores, maternal and paternal } \\
\text { education indicators, race/ethnicity, the one-year lagged county unemployment rate, and the } \\
\text { fraction of high school graduates in a student's state of residence who sent SAT scores to at least } \\
\text { one school. A student is “aid-eligible” if she resides in a zip code with median family income of } \\
\$ 75,000 \text { or less per year. Standard errors are clustered at the state level. }\end{array}$} \\
\hline
\end{tabular}


Table 2: Estimated SAT Score Send Elasticities Associated with an Increase in Tuition and Fees at Public Flagship Institutions

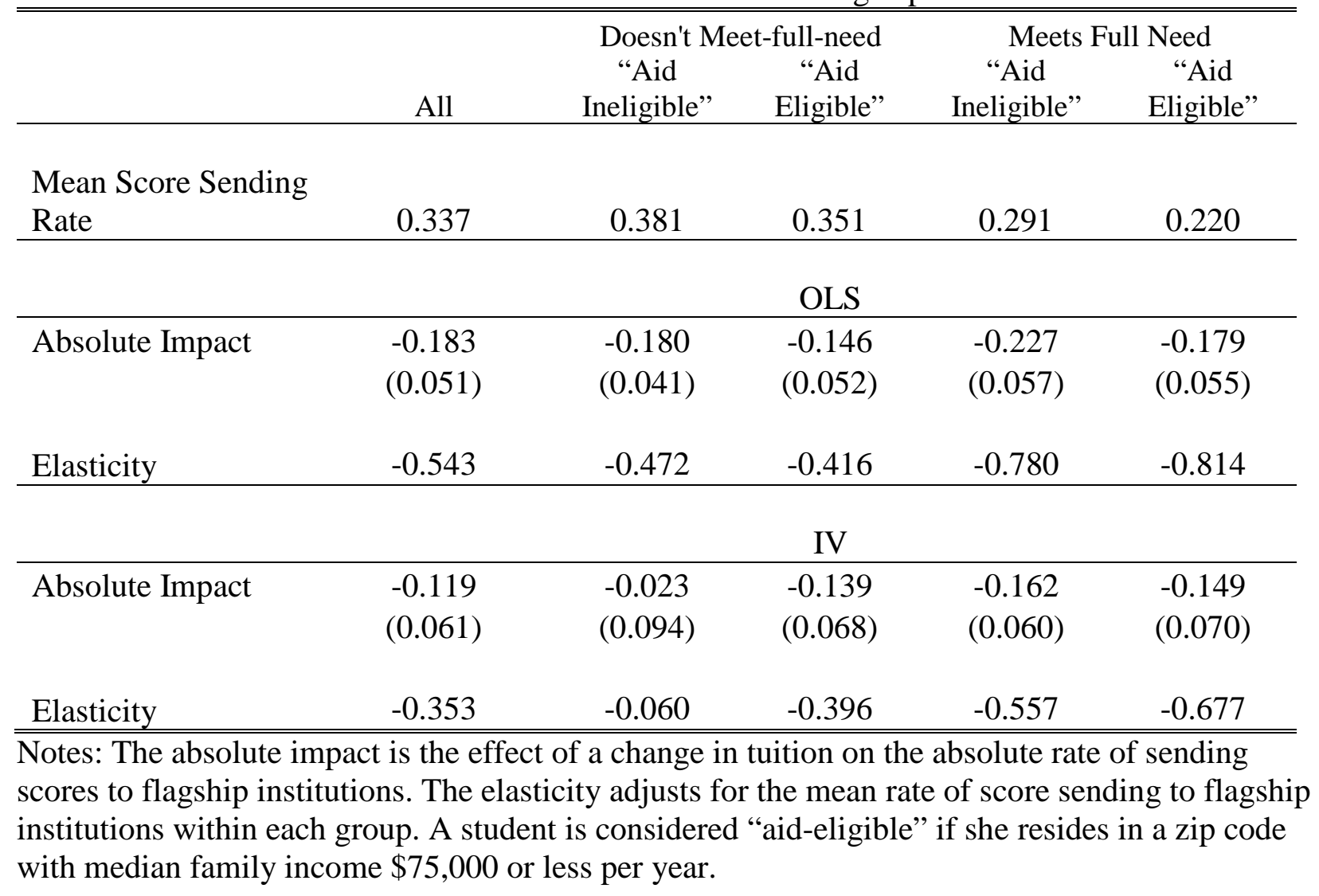


Table 3: Absolute Impact of Increases in Tuition and Fees at Public Flagship Institutions on SAT Score Sending among Different Population Subgroups

\begin{tabular}{|c|c|c|c|c|c|c|c|}
\hline \multirow[b]{2}{*}{$\begin{array}{l}\text { Population } \\
\text { Subgroup }\end{array}$} & \multirow[b]{2}{*}{ Method } & \multirow[b]{2}{*}{$\begin{array}{l}\text { Sample } \\
\text { Size }\end{array}$} & & \multicolumn{2}{|c|}{$\begin{array}{c}\text { Doesn't } \\
\text { Meet-full-need }\end{array}$} & \multicolumn{2}{|c|}{ Meets Full Need } \\
\hline & & & All & $\begin{array}{c}\text { “Aid } \\
\text { Ineligible” }\end{array}$ & $\begin{array}{c}\text { "Aid } \\
\text { Eligible" }\end{array}$ & $\begin{array}{c}\text { “Aid } \\
\text { Ineligible” }\end{array}$ & $\begin{array}{c}\text { "Aid } \\
\text { Eligible" }\end{array}$ \\
\hline \multirow{2}{*}{$\begin{array}{l}\text { SAT Total } \\
\text { above Flagship } \\
\text { Median }\end{array}$} & OLS & $1,487,920$ & $\begin{array}{c}-0.299 \\
(0.100)\end{array}$ & $\begin{array}{c}-0.191 \\
(0.041)\end{array}$ & $\begin{array}{l}-0.198 \\
(0.045)\end{array}$ & $\begin{array}{c}-0.516 \\
(0.068)\end{array}$ & $\begin{array}{c}-0.532 \\
(0.057)\end{array}$ \\
\hline & IV & & $\begin{array}{l}-0.176 \\
(0.122)\end{array}$ & $\begin{array}{c}-0.011 \\
(0.083)\end{array}$ & $\begin{array}{l}-0.170 \\
(0.092)\end{array}$ & $\begin{array}{c}-0.454 \\
(0.068)\end{array}$ & $\begin{array}{c}-0.507 \\
(0.077)\end{array}$ \\
\hline \multirow{3}{*}{$\begin{array}{l}\text { At Least } \\
\text { One Parent } \\
\text { with College } \\
\text { Degree }\end{array}$} & OLS & & $\begin{array}{c}-0.188 \\
(0.049)\end{array}$ & $\begin{array}{l}-0.165 \\
(0.035)\end{array}$ & $\begin{array}{l}-0.147 \\
(0.043)\end{array}$ & $\begin{array}{c}-0.224 \\
(0.051)\end{array}$ & $\begin{array}{c}-0.212 \\
(0.046)\end{array}$ \\
\hline & & $4,073,558$ & & & & & \\
\hline & IV & & $\begin{array}{l}-0.109 \\
(0.055)\end{array}$ & $\begin{array}{c}-0.028 \\
(0.069)\end{array}$ & $\begin{array}{c}-0.135 \\
(0.065)\end{array}$ & $\begin{array}{l}-0.166 \\
(0.057)\end{array}$ & $\begin{array}{l}-0.153 \\
(0.057) \\
\end{array}$ \\
\hline \multirow{3}{*}{ Whites Only } & OLS & & $\begin{array}{c}-0.144 \\
(0.040)\end{array}$ & $\begin{array}{c}-0.146 \\
(0.034)\end{array}$ & $\begin{array}{l}-0.156 \\
(0.044)\end{array}$ & $\begin{array}{c}-0.142 \\
(0.044)\end{array}$ & $\begin{array}{l}-0.127 \\
(0.049)\end{array}$ \\
\hline & & $4,184,386$ & & & & & \\
\hline & IV & & $\begin{array}{l}-0.163 \\
(0.084)\end{array}$ & $\begin{array}{c}-0.136 \\
(0.140)\end{array}$ & $\begin{array}{l}-0.139 \\
(0.079)\end{array}$ & $\begin{array}{l}-0.236 \\
(0.096)\end{array}$ & $\begin{array}{l}-0.172 \\
(0.111)\end{array}$ \\
\hline \multirow{3}{*}{$\begin{array}{l}\text { Under- } \\
\text { Represented } \\
\text { Minorities }\end{array}$} & OLS & & $\begin{array}{c}-0.081 \\
(0.064)\end{array}$ & $\begin{array}{c}-0.116 \\
(0.058)\end{array}$ & $\begin{array}{c}-0.074 \\
(0.060)\end{array}$ & $\begin{array}{c}-0.105 \\
(0.075)\end{array}$ & $\begin{array}{c}-0.072 \\
(0.068)\end{array}$ \\
\hline & & $2,026,872$ & & & & & \\
\hline & IV & & $\begin{array}{l}-0.005 \\
(0.074)\end{array}$ & $\begin{array}{c}0.035 \\
(0.084)\end{array}$ & $\begin{array}{c}-0.012 \\
(0.081)\end{array}$ & $\begin{array}{c}0.025 \\
(0.097)\end{array}$ & $\begin{array}{c}-0.032 \\
(0.079)\end{array}$ \\
\hline \multirow{2}{*}{$\begin{array}{l}\text { Asian- } \\
\text { American }\end{array}$} & OLS & & $\begin{array}{c}-0.321 \\
(0.084)\end{array}$ & $\begin{array}{c}-0.223 \\
(0.060)\end{array}$ & $\begin{array}{l}-0.190 \\
(0.067)\end{array}$ & $\begin{array}{c}-0.404 \\
(0.072)\end{array}$ & $\begin{array}{c}-0.323 \\
(0.071)\end{array}$ \\
\hline & IV & 780,149 & $\begin{array}{l}-0.198 \\
(0.148)\end{array}$ & $\begin{array}{c}0.123 \\
(0.228)\end{array}$ & $\begin{array}{l}-0.035 \\
(0.206)\end{array}$ & $\begin{array}{l}-0.255 \\
(0.115)\end{array}$ & $\begin{array}{l}-0.215 \\
(0.125)\end{array}$ \\
\hline
\end{tabular}

Notes: The absolute impact is the effect of a change in tuition on the absolute rate of sending scores to flagship institutions. 
Table 4: Estimated SAT Score Send Elasticities Associated with an Increase in Tuition and Fees at "Elite" Public Flagship Institutions

\begin{tabular}{lccccc}
\hline & & \multicolumn{2}{c}{ Doesn't Meet-full-need } & \multicolumn{2}{c}{ Meets Full Need } \\
\hline & All & $\begin{array}{c}\text { "Aid } \\
\text { Ineligible" }\end{array}$ & $\begin{array}{c}\text { "Aid } \\
\text { Eligible" }\end{array}$ & $\begin{array}{c}\text { "Aid } \\
\text { Ineligible" }\end{array}$ & $\begin{array}{c}\text { "Aid } \\
\text { Eligible" }\end{array}$ \\
& & & OLS & & \\
\hline Absolute Impact & -0.136 & -0.167 & -0.100 & -0.173 & -0.122 \\
p-value (clustered) & $(0.015)$ & $(0.001)$ & $(0.028)$ & $(0.010)$ & $(0.031)$ \\
p-value (wild bootstrap) & {$[0.035]$} & {$[0.026]$} & {$[0.181]$} & {$[0.123]$} & {$[0.151]$} \\
\hline & & & & & \\
\hline Absolute Impact & -0.097 & -0.085 & -0.093 & -0.130 & -0.117 \\
p-value (clustered) & $(0.071)$ & $(0.378)$ & $(0.080)$ & $(0.046)$ & $(0.119)$ \\
p-value (wild bootstrap) & {$[0.269]$} & {$[0.558]$} & {$[0.268]$} & {$[0.149]$} & {$[0.365]$} \\
\hline \hline
\end{tabular}

Notes: The models estimated to arrive at these elasticities are identical to those reported in Tables 1 and 2 except the data are limited to students living in the 17 states with median math and verbal combined SAT scores of greater than 1200 . The sample size is 5,565,617. P-values based on traditional, clustered standard errors are reported along with p-values estimated using wild bootstrap methods that correct for the limited number of clusters. 
Table 5: Estimated Impact of Tuition Increases on SAT Scores at Public Flagships and Enrollment at Different Types of Institutions

\begin{tabular}{|c|c|c|c|c|c|}
\hline & & \multicolumn{2}{|c|}{ Doesn't Meet-full-need } & \multicolumn{2}{|c|}{ Meets Full Need } \\
\hline & All & $\begin{array}{c}\text { “Aid } \\
\text { Ineligible” }\end{array}$ & $\begin{array}{c}\text { “Aid } \\
\text { Eligible” }\end{array}$ & $\begin{array}{c}\text { “Aid } \\
\text { Ineligible” }\end{array}$ & $\begin{array}{c}\text { "Aid } \\
\text { Eligible" }\end{array}$ \\
\hline & \multicolumn{5}{|c|}{ All Students $(\mathrm{N}=7,589,048)$} \\
\hline $\begin{array}{l}\text { Public Flagship } \\
\text { Enrollment }\end{array}$ & $\begin{array}{l}-0.015 \\
(0.009)\end{array}$ & $\begin{array}{l}-0.020 \\
(0.010)\end{array}$ & $\begin{array}{c}-0.011 \\
(0.010)\end{array}$ & $\begin{array}{l}-0.031 \\
(0.011)\end{array}$ & $\begin{array}{c}0.005 \\
(0.015)\end{array}$ \\
\hline & \multicolumn{5}{|c|}{ All SAT Takers Enrolled in Public Flagships $(\mathrm{N}=671,830)$} \\
\hline $\begin{array}{l}\text { Public Flagship } \\
\text { Average Combined } \\
\text { SAT Score }\end{array}$ & $\begin{array}{l}-22.4 \\
(7.8)\end{array}$ & $\begin{array}{l}-18.7 \\
(9.6)\end{array}$ & $\begin{array}{l}-27.0 \\
(7.0)\end{array}$ & $\begin{array}{l}-16.0 \\
(18.7)\end{array}$ & $\begin{array}{l}-41.8 \\
(21.1)\end{array}$ \\
\hline & \multicolumn{5}{|c|}{ High Achieving Students $(\mathrm{N}=1,487,920)$} \\
\hline $\begin{array}{l}\text { Public Flagship } \\
\text { Enrollment }\end{array}$ & $\begin{array}{l}-0.074 \\
(0.023)\end{array}$ & $\begin{array}{l}-0.059 \\
(0.022)\end{array}$ & $\begin{array}{l}-0.052 \\
(0.021)\end{array}$ & $\begin{array}{l}-0.114 \\
(0.015)\end{array}$ & $\begin{array}{l}-0.117 \\
(0.022)\end{array}$ \\
\hline $\begin{array}{l}\text { Public 4-Year } \\
\text { Non-Flagship } \\
\text { Enrollment }\end{array}$ & $\begin{array}{l}-0.048 \\
(0.023)\end{array}$ & $\begin{array}{l}-0.016 \\
(0.020)\end{array}$ & $\begin{array}{l}-0.049 \\
(0.024)\end{array}$ & $\begin{array}{l}-0.082 \\
(0.017)\end{array}$ & $\begin{array}{l}-0.086 \\
(0.021)\end{array}$ \\
\hline $\begin{array}{l}\text { Public Out-of-State } \\
\text { Flagship Enrollment }\end{array}$ & $\begin{array}{c}0.013 \\
(0.011)\end{array}$ & $\begin{array}{c}0.002 \\
(0.011)\end{array}$ & $\begin{array}{c}0.005 \\
(0.009)\end{array}$ & $\begin{array}{c}0.033 \\
(0.008)\end{array}$ & $\begin{array}{c}0.045 \\
(0.015)\end{array}$ \\
\hline $\begin{array}{l}\text { Private 4-Year } \\
\text { Enrollment }\end{array}$ & $\begin{array}{c}0.075 \\
(0.024)\end{array}$ & $\begin{array}{c}0.033 \\
(0.019)\end{array}$ & $\begin{array}{c}0.080 \\
(0.021)\end{array}$ & $\begin{array}{c}0.116 \\
(0.016)\end{array}$ & $\begin{array}{c}0.115 \\
(0.015)\end{array}$ \\
\hline $\begin{array}{l}\text { Private, 4-Year MFN } \\
\text { Enrollment }\end{array}$ & $\begin{array}{c}0.009 \\
(0.009)\end{array}$ & $\begin{array}{l}-0.009 \\
(0.009)\end{array}$ & $\begin{array}{c}0.022 \\
(0.011)\end{array}$ & $\begin{array}{c}0.015 \\
(0.009)\end{array}$ & $\begin{array}{c}0.026 \\
(0.015)\end{array}$ \\
\hline
\end{tabular}

Notes: All estimates are obtained from OLS models of the same form as those reported in Table 1 using National Student Clearinghouse data for all SAT score senders. "High achievers" are defined as those whose combined SAT scores are above the "median" of students enrolled in the student's public flagship institution. The "median" is defined to be the midpoint between the $25^{\text {th }}$ and $75^{\text {th }}$ percentile of combined SAT scores, as reported in IPEDS. 


\section{Appendix 1: Timing of the Admissions Process and Lags Used in Our Econometric Analysis}

To understand the lagging of tuition and fees and state and county unemployment rates in this specification, it is helpful to think about the typical timeline for college-going. Consider the

cohort of students graduating from high school in 2013. These students would (potentially) enroll in college in September 2013. Most public institutions release their tuition and fees rates for the 2013-14 school year in July 2013. This is after the student decides whether to apply and enroll because the student submits applications in December 2012 and decides where to enroll in April 2013.

\section{SAT Score Sending Timing, 2013 Cohort}

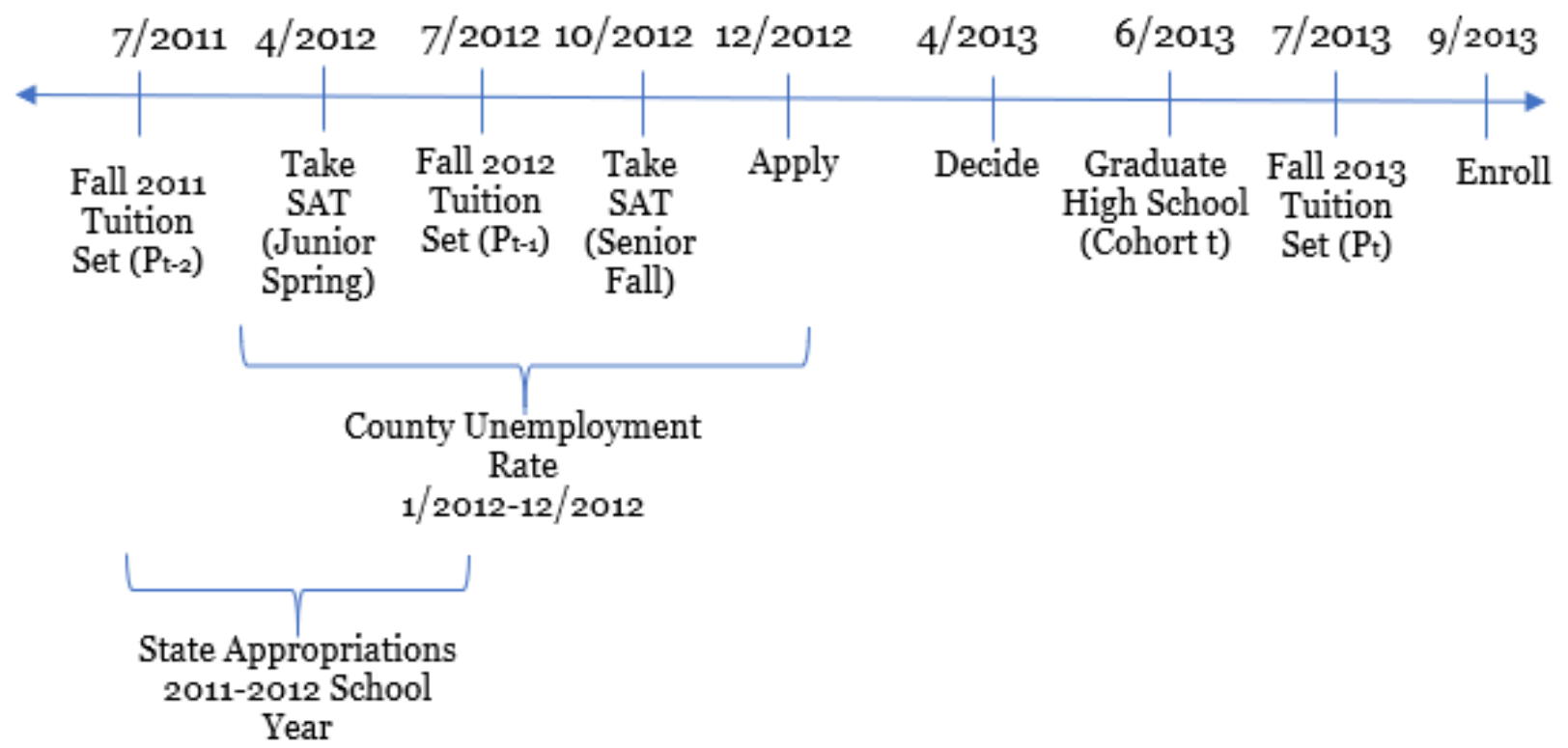

Most students will take the SAT during the spring of their junior year and/or the fall of their senior year. They will send their SAT scores to colleges either at or right after the time of SAT administration when they can use one of their four free score sends, or around the time they submit their full applications, which requires paying around \$10 per score-send. If students decide where to apply and send scores in the fall of their senior year, the most recent price 
information available to them corresponds to the 2012-13 school year. The actual 2013-14 college prices they will face are likely not released until July 2013, after they graduate high school. However, if they make their college application and score-send decisions in the spring of their junior year, only tuition and fees for 2011-12 would be available.

In our preferred specification, we opt to use the 2012-13 prices (i.e. tuition and fees lagged 1 academic year relative to their matriculation/cohort year) as our explanatory variable which assumes that students make application decisions in their senior year. However, we have tested robustness to lagging two years, which assumes that students make application decisions in their junior year, and the results are similar. We lag the county unemployment rate 1 year. For the 2013 cohort, this means that we use the county unemployment rate over the January 2012 to December 2012 period, which covers the entire spring junior year and fall senior year period over which students are typically deciding where to send their SAT scores. In the IV specifications, we use state appropriations from the student's junior year (appropriations from 2011-2012 for a student graduating high school in June 2013). 


\section{Appendix Figures}

Figure A.1: Percent of High School Graduates Taking SAT and Sending at Least One Score Report

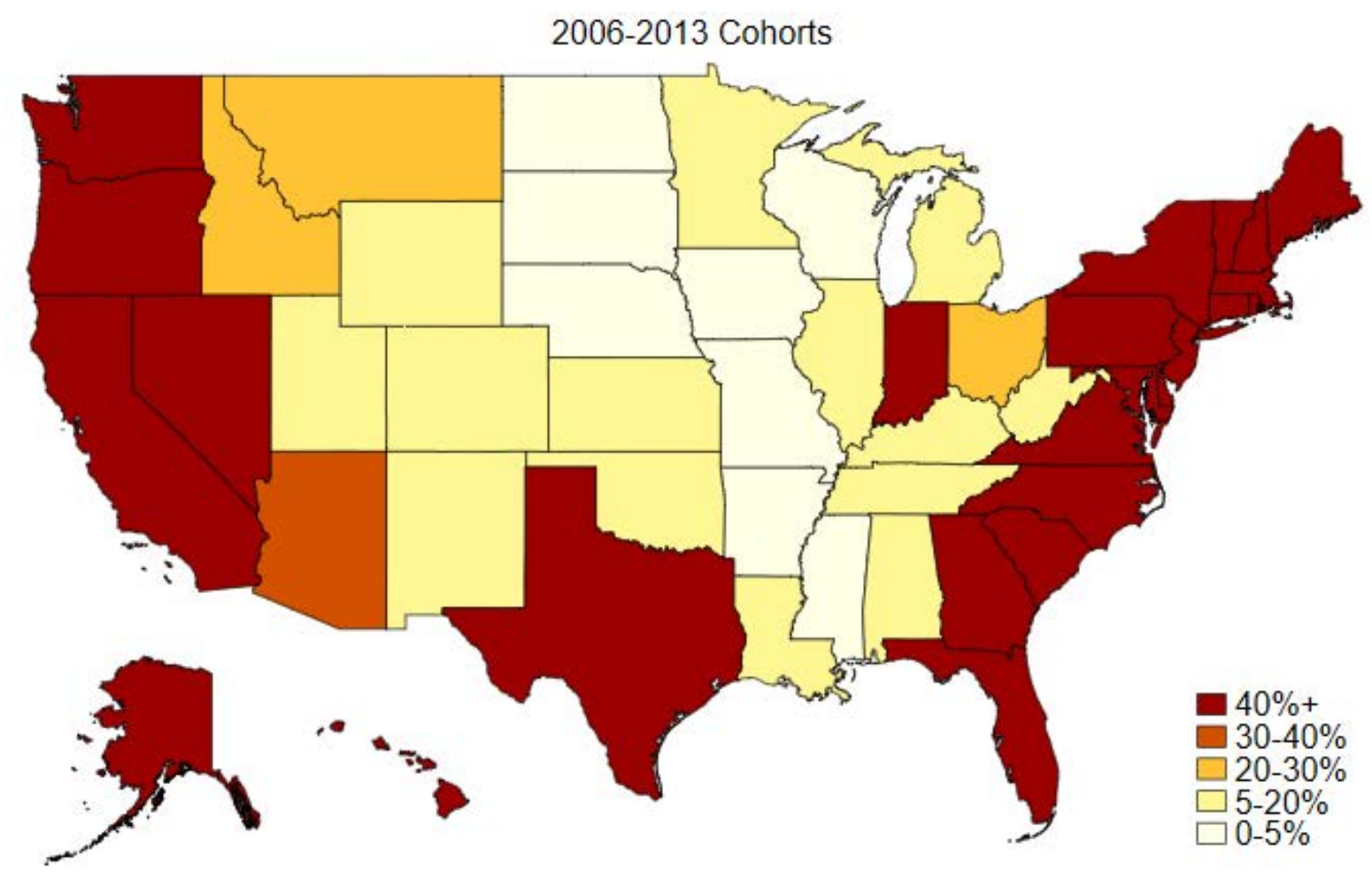

Notes: The number of high school graduates in each state comes from Western Interstate Commission for Higher Education (2016). The number of students taking the SAT and sending at least one score comes from the College Board data sample as described in the text. 


\title{
Figure A.2: Trends in Enrollment Rates at Flagship Institutions
}

\author{
By Severity of the Recession
}

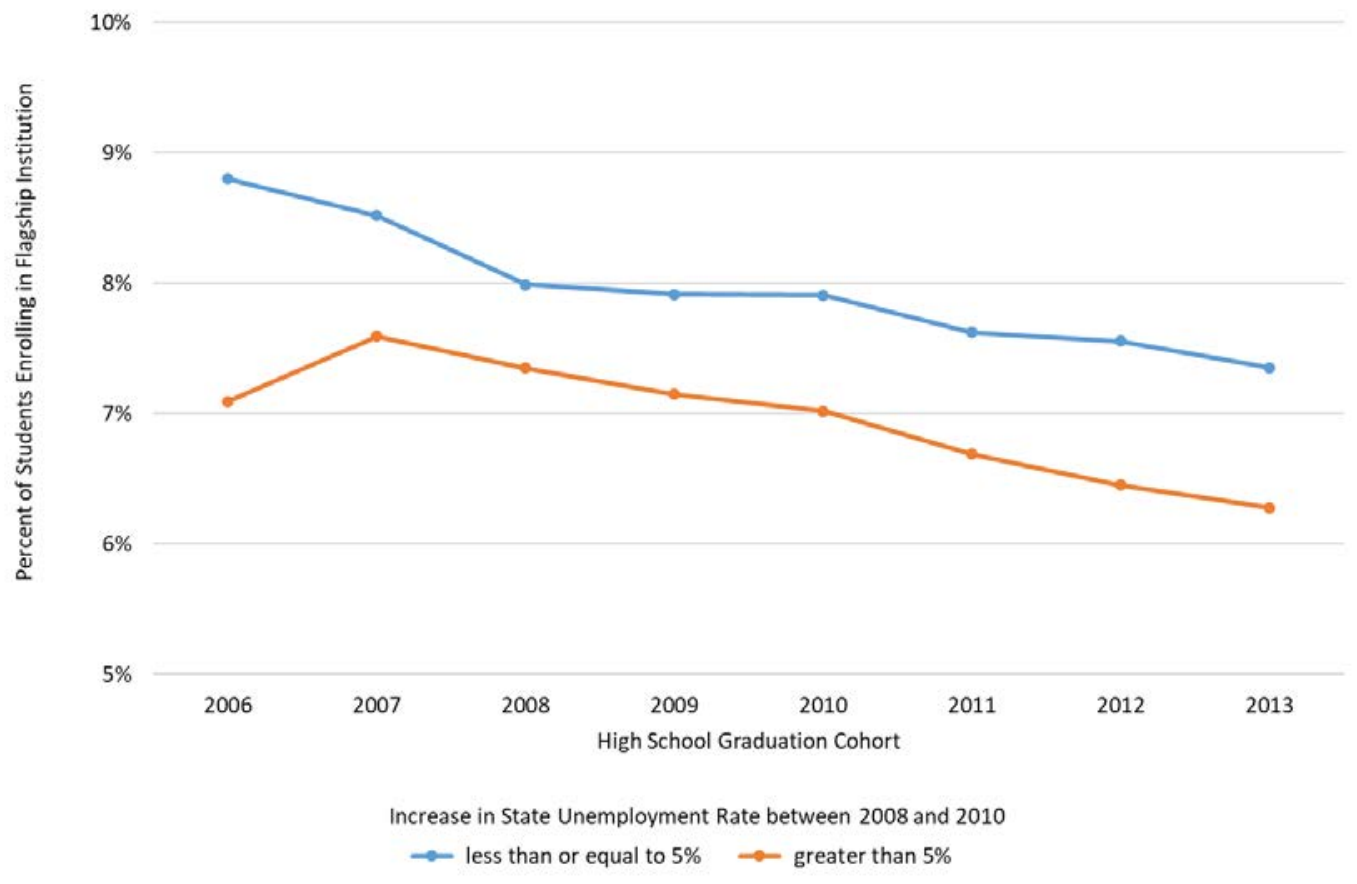

By Meet-Full-Need Status

$12 \%$

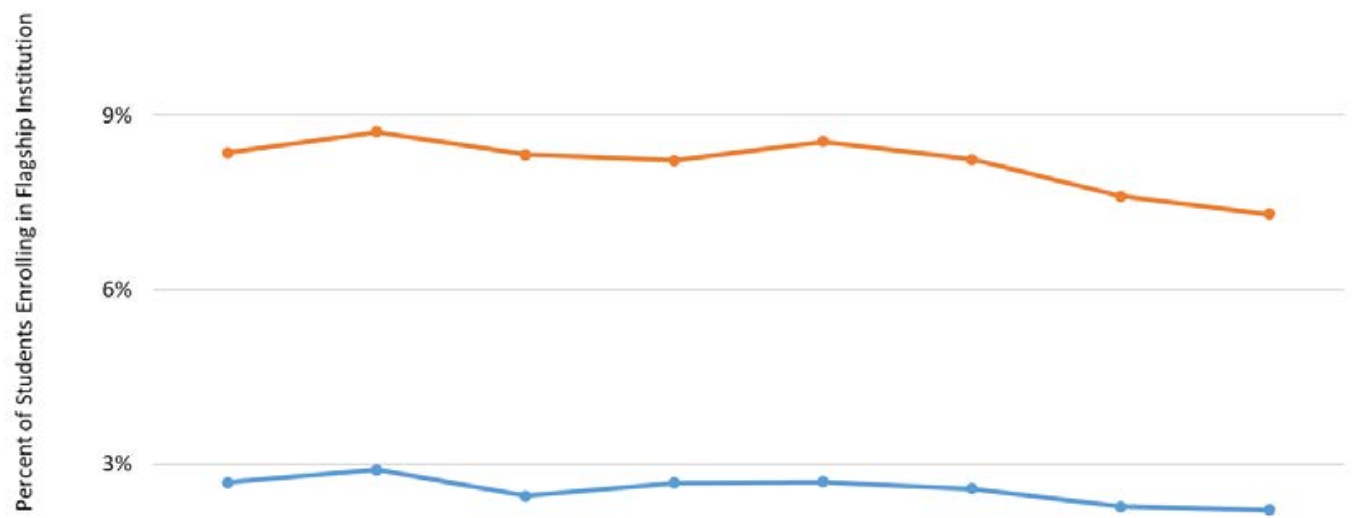

$0 \%$

\begin{tabular}{|c|c|c|c|c|c|c|c|}
\hline 2006 & 2007 & 2008 & 2009 & 2010 & 2011 & 2012 & 2013 \\
\hline \multicolumn{8}{|c|}{ High School Graduation Cohort } \\
\hline
\end{tabular}

Notes: The enrollment rate reflects the percentage of students enrolled at their home state's flagship as a percentage of students who sent an SAT score report to at least one institution. 
Figure A.3: Difference in Enrollment Rate at Flagship Institutions, by Families' Aid-Eligibility Status and Schools' "Meet Full Need" Status

0.02

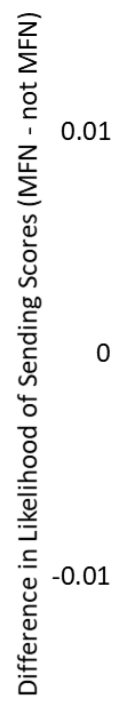

$-0.02$

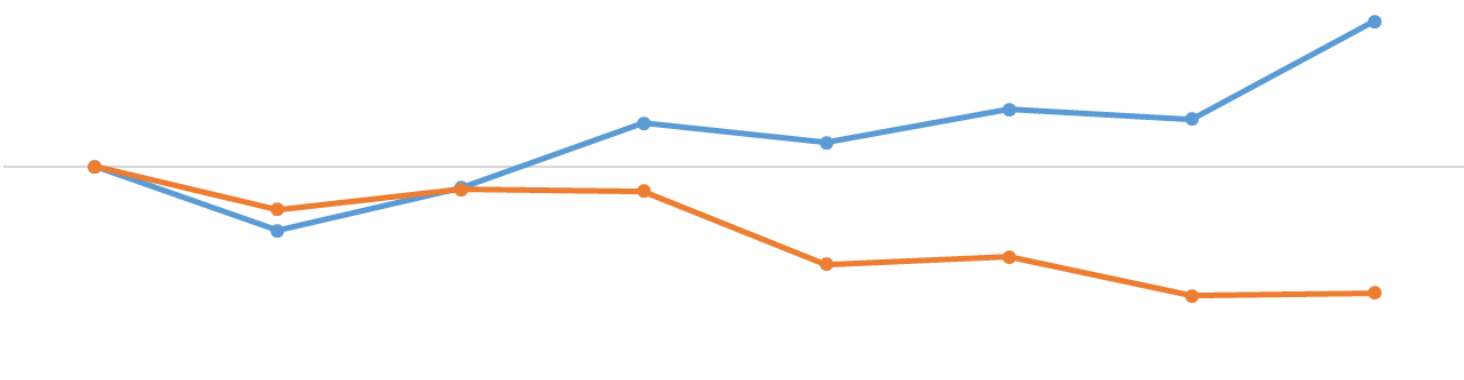


Appendix Table A.1: List of Flagship Institutions

\begin{tabular}{|c|c|}
\hline AK & University of Alaska - Fairbanks \\
\hline $\mathrm{AL}$ & University of Alabama \\
\hline AR & University of Arkansas \\
\hline CA & University of California - Berkeley \\
\hline $\mathrm{CO}$ & University of Colorado at Boulder \\
\hline $\mathrm{CT}$ & University of Connecticut \\
\hline $\mathrm{DE}$ & University of Delaware \\
\hline FL & University of Florida \\
\hline GA & University of Georgia \\
\hline HI & University of Hawaii at Manoa \\
\hline IA & University of Iowa \\
\hline ID & University of Idaho \\
\hline IL & University of Illinois at Urbana-Champaign \\
\hline IN & Indiana University - Bloomington \\
\hline KS & University of Kansas \\
\hline KY & University of Kentucky \\
\hline LA & Louisiana State University and Agricultural \& Mechanical College \\
\hline MA & University of Massachusetts - Amherst \\
\hline MD & University of Maryland - College Park \\
\hline ME & University of Maine \\
\hline MI & University of Michigan - Ann Arbor \\
\hline MN & University of Minnesota - Twin Cities \\
\hline MO & University of Missouri - Columbia \\
\hline MS & University of Mississippi \\
\hline MT & University of Montana \\
\hline NC & University of North Carolina at Chapel Hill \\
\hline ND & University of North Dakota \\
\hline $\mathrm{NE}$ & University of Nebraska - Lincoln \\
\hline $\mathrm{NH}$ & University of New Hampshire \\
\hline NJ & Rutgers University - New Brunswick \\
\hline NM & University of New Mexico \\
\hline NV & University of Nevada - Reno \\
\hline NY & State University of New York at Buffalo \\
\hline $\mathrm{OH}$ & Ohio State University \\
\hline OK & University of Oklahoma - Norman \\
\hline OR & University of Oregon \\
\hline PA & Pennsylvania State University \\
\hline RI & University of Rhode Island \\
\hline SC & University of South Carolina - Columbia \\
\hline SD & University of South Dakota \\
\hline $\mathrm{TN}$ & University of Tennessee - Knoxville \\
\hline TX & University of Texas at Austin \\
\hline UT & University of Utah \\
\hline VA & University of Virginia \\
\hline VT & University of Vermont \\
\hline WA & University of Washington - Seattle \\
\hline
\end{tabular}


WI University of Wisconsin - Madison

WV West Virginia University

WY University of Wyoming 
Table A.2: Alternative Specifications of the Absolute Impact of Increases in Tuition and Fees at Public Flagship Institutions on SAT Score Sending

\begin{tabular}{|c|c|c|c|c|c|c|c|}
\hline \multirow[b]{2}{*}{$\begin{array}{l}\text { Population } \\
\text { Subgroup }\end{array}$} & \multirow[b]{2}{*}{ Method } & \multirow[b]{2}{*}{$\begin{array}{c}\text { Sample } \\
\text { Size }\end{array}$} & & \multicolumn{2}{|c|}{ Doesn't Meet-full-need } & \multicolumn{2}{|c|}{ Meets Full Need } \\
\hline & & & All & $\begin{array}{c}\text { “Aid } \\
\text { Ineligible” }\end{array}$ & $\begin{array}{c}\text { “Aid } \\
\text { Eligible" }\end{array}$ & $\begin{array}{c}\text { “Aid } \\
\text { Ineligible” }\end{array}$ & $\begin{array}{c}\text { "Aid } \\
\text { Eligible" }\end{array}$ \\
\hline $\begin{array}{c}\text { Low- } \\
\text { Income }\end{array}$ & OLS & & $\begin{array}{c}-0.153 \\
(0.046)\end{array}$ & $\begin{array}{l}-0.166 \\
(0.039)\end{array}$ & $\begin{array}{l}-0.165 \\
(0.054)\end{array}$ & $\begin{array}{l}-0.101 \\
(0.054)\end{array}$ & $\begin{array}{c}-0.138 \\
(0.059)\end{array}$ \\
\hline $\begin{array}{l}\text { Definition: } \\
\text { Self- } \\
\text { Reported } \\
<\$ 100,000 \\
\end{array}$ & IV & $7,589,048$ & $\begin{array}{l}-0.075 \\
(0.064)\end{array}$ & $\begin{array}{c}-0.074 \\
(0.074)\end{array}$ & $\begin{array}{l}-0.074 \\
(0.061)\end{array}$ & $\begin{array}{l}-0.054 \\
(0.091)\end{array}$ & $\begin{array}{l}-0.119 \\
(0.103)\end{array}$ \\
\hline $\begin{array}{c}\text { Low- } \\
\text { Income } \\
\text { Definition: }\end{array}$ & OLS & & $\begin{array}{c}-0.180 \\
(0.051)\end{array}$ & $\begin{array}{c}-0.161 \\
(0.043)\end{array}$ & $\begin{array}{l}-0.202 \\
(0.055)\end{array}$ & $\begin{array}{c}-0.079 \\
(0.064)\end{array}$ & $\begin{array}{l}-0.155 \\
(0.059)\end{array}$ \\
\hline $\begin{array}{c}\text { Median Zip } \\
\text { Code } \\
\text { Income } \\
<\$ 50,000 \\
\end{array}$ & IV & $7,589,048$ & $\begin{array}{l}-0.113 \\
(0.061)\end{array}$ & $\begin{array}{c}-0.097 \\
(0.067)\end{array}$ & $\begin{array}{c}-0.158 \\
(0.063)\end{array}$ & $\begin{array}{c}-0.103 \\
(0.143)\end{array}$ & $\begin{array}{c}-0.175 \\
(0.111)\end{array}$ \\
\hline $\begin{array}{c}\text { Low- } \\
\text { Income } \\
\text { Definition: }\end{array}$ & OLS & & $\begin{array}{c}-0.182 \\
(0.182)\end{array}$ & $\begin{array}{c}-0.166 \\
(0.166)\end{array}$ & $\begin{array}{c}-0.203 \\
(0.203)\end{array}$ & $\begin{array}{c}-0.126 \\
(0.126)\end{array}$ & $\begin{array}{l}-0.197 \\
(0.197)\end{array}$ \\
\hline $\begin{array}{c}\text { No Parent } \\
\text { with } \\
\text { Any } \\
\text { College }\end{array}$ & IV & $7,589,048$ & $\begin{array}{c}-0.116 \\
(0.061)\end{array}$ & $\begin{array}{c}-0.095 \\
(0.069)\end{array}$ & $\begin{array}{c}-0.141 \\
(0.063)\end{array}$ & $\begin{array}{c}-0.114 \\
(0.079)\end{array}$ & $\begin{array}{l}-0.213 \\
(0.114)\end{array}$ \\
\hline $\begin{array}{l}\text { States } \\
\text { Where }\end{array}$ & OLS & & $\begin{array}{l}-0.189 \\
(0.058)\end{array}$ & $\begin{array}{c}-0.182 \\
(0.048)\end{array}$ & $\begin{array}{c}-0.235 \\
(0.061)\end{array}$ & $\begin{array}{c}-0.144 \\
(0.058)\end{array}$ & $\begin{array}{l}-0.180 \\
(0.059)\end{array}$ \\
\hline Taking & & $6,886,556$ & & & & & \\
\hline $\begin{array}{c}\text { SAT } \\
\text { is Common }\end{array}$ & IV & & $\begin{array}{c}-0.137 \\
(0.066)\end{array}$ & $\begin{array}{c}-0.056 \\
(0.102)\end{array}$ & $\begin{array}{l}-0.190 \\
(0.065)\end{array}$ & $\begin{array}{c}-0.151 \\
(0.071)\end{array}$ & $\begin{array}{l}-0.159 \\
(0.074)\end{array}$ \\
\hline $\begin{array}{l}\text { Omit } \\
\text { California }\end{array}$ & OLS & $6,309,284$ & $\begin{array}{l}-0.153 \\
(0.051)\end{array}$ & $\begin{array}{c}-0.172 \\
(0.044)\end{array}$ & $\begin{array}{c}-0.172 \\
(0.104)\end{array}$ & $\begin{array}{c}-0.142 \\
(0.056)\end{array}$ & $\begin{array}{l}-0.187 \\
(0.107)\end{array}$ \\
\hline Sample & IV & & $\begin{array}{l}-0.099 \\
(0.070)\end{array}$ & $\begin{array}{l}-0.018 \\
(0.093)\end{array}$ & $\begin{array}{l}-0.070 \\
(0.110)\end{array}$ & $\begin{array}{l}-0.133 \\
(0.076)\end{array}$ & $\begin{array}{c}-0.056 \\
(0.115)\end{array}$ \\
\hline
\end{tabular}

Notes: The absolute impact is the effect of a change in tuition on the absolute rate of sending scores to flagship institutions. 
Table A.3: Estimated Impacts of Increases in Cost of Attendance at Public Flagship Institutions (Logs)

\begin{tabular}{|c|c|c|}
\hline & OLS & IV \\
\hline \multicolumn{3}{|c|}{ Aggregate } \\
\hline $\ln$ (cost of attendance, lagged one year) & $\begin{array}{l}-0.159 \\
(0.062)\end{array}$ & $\begin{array}{l}-0.467 \\
(0.288)\end{array}$ \\
\hline First Stage F-Statistic & --- & 4.87 \\
\hline \multicolumn{3}{|c|}{ Triple Difference } \\
\hline $\ln$ (cost of attendance) & $\begin{array}{c}-0.087 \\
(0.136)\end{array}$ & $\begin{array}{c}-0.256 \\
(0.303)\end{array}$ \\
\hline $\ln$ (cost of attendance*“aid eligible”) & $\begin{array}{c}-0.255 \\
(0.080)\end{array}$ & $\begin{array}{r}-0.615 \\
(0.914)\end{array}$ \\
\hline $\ln ($ cost of attendance*meet-full-need) & $\begin{array}{c}-0.041 \\
(0.104)\end{array}$ & $\begin{array}{c}-0.440 \\
(0.270)\end{array}$ \\
\hline $\ln \left(\mathrm{COA}^{*}\right.$ meet-full-need*“aid eligible”) & $\begin{array}{c}-0.182 \\
(0.069)\end{array}$ & $\begin{array}{r}-0.329 \\
(0.806) \\
\end{array}$ \\
\hline Kleibergen and Paap Wald Rank F Test & --- & 0.19 \\
\hline \multicolumn{3}{|c|}{$\begin{array}{l}\text { Notes: Estimates are obtained from a model of the form of equations } 1 \text { through } 3 \text { and based on } \\
\text { the authors' analysis of College Board data on scores sent to students' in-state flagship universit } \\
\text { among those who took the SAT and sent scores to at least one college. Additional explanatory } \\
\text { variables include: the students' SAT math and verbal scores, maternal and paternal education } \\
\text { indicators, race/ethnicity, the one-year lagged county unemployment rate, and the fraction of } \\
\text { SAT takers in a student's high school graduating cohort who sent any scores to schools. A } \\
\text { student is "aid eligible" if she resides in a zip code with median family income of } \$ 75,000 \text { or les } \\
\text { per year. Standard errors are clustered at the state level. }\end{array}$} \\
\hline
\end{tabular}

